\title{
Yiddish Possessives as a Case for Genitive Case*
}

Yiddish is standardly characterised as a language with a three-case system, differentiating between nominative, accusative and dative. Possessor noun phrases that occur before the possessum appear to be marked by dative and an additional formative $-s$, which attaches to the head noun at the right edge of the possessor phrase. This article presents evidence for considering the possessive marker part of the exponence of genitive case, and thus, for revising the description of the Yiddish case system. The arguments given concern, on the one hand, the morphosyntactic status of the possessive marker and, on the other, the fact that, upon closer inspection, the nominal with which the possessive marker is combined is not identical with a noun phrase case-marked for dative.

\section{Introduction}

If Yiddish is the "archetypical "dying language" (Fishman 2001: 75), proclaimed to be on the verge of obsolescence since the mid-twentieth century, the genitive may be dubbed the proverbial 'case in decline' in the Germanic languages. It may then seem unsurprising that Yiddish, which presents evidence of constructional loss vis-à-vis its stock language German (so, for example, in the tense system), is commonly described as having a threecase system of nominative, accusative and dative, lacking genitive case. Equally unsurprising, however, may be that Yiddish, like many other languages, codes adnominal possessive relations by means of a possessive marker associated with the possessor. This is exemplified in (1), which shows the possessor lerer, 'teacher', to bear the formative $-s$.

$$
\begin{aligned}
& \text { a lerer-s bukh }{ }^{1,2} \\
& \text { a teacher-s book } \\
& \text { 'a teacher's book' }
\end{aligned}
$$

The central question explored in this article is whether Yiddish possessive marking can be justifiably analysed as an instance of morphological genitive case. As noted by Taylor (1996: 117), the answer to the question whether a possessive marker

\footnotetext{
${ }^{*}$ For acceptability judgments, discussion and useful suggestions, I am thankful to Helen Beer, Gennady Estraikh, Manrico Glauser, Martin Maiden, Louise Mycock, Pascal Romann, and Séan Williams. I am also grateful to the two anonymous referees whose queries and constructive comments led me to rethink the focus of the argument. Finally, I am much indebted to the editors of this volume for their patience and encouragement.

${ }^{1}$ All data cited in this article reflect the acceptability judgments of native speakers, unless attributed to other sources. The Yiddish data were collected from two native speakers of Central and Northeastern Yiddish, respectively, schooled in the secular Yiddish school system. The Fribourg German data correspond to the judgments of a single speaker from Wünnewil, while the Colloquial German data were checked with a speaker from Berlin.
}

${ }^{2}$ All Yiddish examples and titles have been transliterated according to the conventions of Standardised Yiddish Romanisation, developed by the YIVO Institute for Jewish Research (see Weinreich 1968: xx-xxi). 
constitutes a genitive case affix depends on the definition of case marking, which is not always consistent across the literature. Setting aside 'extended' case concepts such as deep (Fillmore 1968) or abstract (Chomsky 1981) case, a widely accepted definition construes case as an 'inflectional category-system expressing dependency relations' (Haspelmath 2009: 507). This definition defines case in terms of both form and function: case is realised as a change in the shape of a word, and has the function of 'marking dependent nouns for the type of relationship they bear to their heads' (Blake 2001: 1). The question of whether the Yiddish possessive marker can be considered an exponent of genitive case then splits into two: (i) Is Yiddish possessive marking achieved by morphological means?; and (ii) Does Yiddish possessive marking target a noun that stands in a particular dependency relation to another head?

While the answer to the second question is unambiguously yes (because Yiddish possessive marking is nominal marking of the dependent in the possessive relation), answering the first question, which requires evidence for the affixal nature of Yiddish possessive marking, proves trickier. By necessity, the task of categorising a marker as an affix proceeds from the assumption that affixes exist as a cross-linguistically identifiable category, which can be diagnosed by a set of criteria, such as those developed in Zwicky \& Pullum (1983). This assumption is questioned by approaches that understand affixes, clitics and grammatical words to be distributed over a continuum of boundedness (as, for example, Aikhenvald 2002). ${ }^{3}$ If no clear dividing line can be drawn between affixes and other formatives, the notion of affix is at best a fuzzy concept, rendering the answer to the question of whether a given morpheme is a morphological case marker potentially indeterminable or, worse yet, meaningless. ${ }^{4}$

On the other hand, if affixes are not a delimitable grammatical category, case could be said to have a wider range of morphosyntactic realisations than permitted by a definition that understands it to be an 'inflectional category-system'. In other words, a given marker coding a specific dependency relation between a noun and its head would always be the exponent of a particular case value, regardless of its morphosyntactic properties. This view corresponds to the common practice of using the term genitive for both nominal inflection and adpositions in possessor phrases.

Does it then follow that all possessive marking on a dependent nominal is genitive case? This is denied in the literature: surveying the analyses of Dutch and German prenominal possessors ending in $-s$, Allen (2008: 47) concludes that in these languages, ' $-s$ should not be considered a case marker' on the basis of the asymmetries that exist between $-s$ possessors and other genitive noun phrases in Dutch and German. These asymmetries include (i) the absence of possessive-marked nouns in other genitive contexts (e.g. as prepositional complements), (ii) the lack of evidence for concordial case marking in the possessor phrase, and (iii) the restriction of possessive marking to proper names (or nominal phrases reanalysed as proper names; see Hartmann \& Zimmermann 2002) and to possessors in prenominal position. It is thus not the absence of idiosyncracy and exceptionality (as in Zwicky \& Pullum's 1983 diagnostics for distinguishing clitics

\footnotetext{
${ }^{3}$ See also Embick \& Noyer (2001: 592), for whom the distinction between clitics and affixes is 'a cumbersome artifact of lexicalism'.

${ }^{4}$ This position accords with that of Haspelmath (2011), who argues that there is no motivation for making a distinction between morphology and syntax, if it turns out to be the case that grammatical units do not cluster on the continuum of boundedness, but are randomly distributed. He concludes that morphosyntax is 'currently best viewed as a unitary domain' (Haspelmath 2011: 72).
} 
from affixes) that disqualifies the possessive formative from being an affix, but rather its distinct behaviour from that of other members of the genitive case category.

Yiddish is a language in which there appears to be no justification for genitive case other than prenominal possessive marking, given that verbal and prepositional objects can be unambiguously identified as either accusative or dative. With no unequivocal genitive case forms to serve as standard of comparison, what criteria would possessive marking have to meet in order to qualify as genitive case? The argument pursued in this article is that in a language with morphological case, possessive marking can be labelled genitive if (i) the possessor phrase is not overtly marked for another case, and (ii) the possessive marker displays affix-like behaviour. In other words, in line with Haspelmath's (2009: 513) dictum that the 'term genitive for the case of the possessor is relatively unproblematic, and there seems to be no strong reason to rename it possessive case', it can be assumed that in a morphological case-marking language, possessors bear genitive case if the possessor in an adnominal possessive construction does not decompose into a string that consists of a nominal marked for nominative, accusative or dative case, followed by a non-affixal possessive marker.

The task then becomes to show that:

- Yiddish is a language with morphological case;

- Yiddish uses a possessive marker that has affixal properties;

- Yiddish marks adnominal possessive relations by means of a case form distinct from nominative, accusative or dative.

The claim made here is that all three of these statements are empirically correct, and that Yiddish can hence be considered a four-case language, with nominative, accusative, genitive and dative. The discussion of the evidence proceeds as follows: Section 2 introduces Yiddish as a language with morphological case, and presents the received view of Yiddish possessive marking as involving a dative noun phrase combined with a possessive marker. Section 3 considers the morphosyntactic status of this possessive marker, comparing Yiddish to possessor doubling constructions in other Germanic varieties, and arguing that Yiddish possessive $-s$ patterns with affixes in both its degree of attachment and type of placement. Section 4 charts the development of Yiddish possessive marking from the Middle Yiddish period, demonstrating and seeking an explanation for the fact that not all possessor forms are isomorphic with a dative nominal combined with - s. The article concludes in Section 5 by reviewing the principal findings.

\section{The Yiddish Case System}

Most grammars and textbooks of Yiddish (see, for example, Mark 1978: 173; Weinreich 1981: 306; Katz 1987a: 75) describe (Standard) Yiddish as having three morphological cases - nominative, accusative and dative. ${ }^{5}$ Case is overtly marked on definite

\footnotetext{
${ }^{5}$ Standard Yiddish is the outcome of modern Yiddish language planning, closely associated with the work of the YIVO Institute of Jewish Research, founded in Vilna in 1925 (see Fishman 2008 for a discussion of the principles that underpinned Yiddish standardisation). It is best described as a compromise variety that contains features found across the Yiddish dialect continuum (Jacobs 2005: 287). While the existence of a spoken standard is frequently called into question (see, for example, Birnbaum 1979: 100), it is generally accepted that the morphological and syntactic norms of the standard variety,
} 
determiners, but not generally on nouns, where only a subset is inflected. This subset encompasses proper nouns and a small number of common nouns, which predominantly have human referents, denoting kinship terms and social relations: tate 'father', zeyde 'grandfather', and rebe '(traditional) rabbi, teacher' are obligatorily inflected with the suffix $-n$ to mark accusative and dative case, while yid 'Jew, man', mentsh 'person', mame 'mother', bobe 'grandmother', mume 'aunt' and harts 'heart' are optionally inflected with - $n$ for either accusative and dative case (for the masculine nouns yid and mentsh) or merely dative case (for the feminine nouns mame, bobe and mume, and the neuter noun harts). Case marking also appears on modifying adjectives by agreement with the head noun. Table 1 shows the Yiddish case paradigm as routinely presented in the literature, exemplifying both non-inflecting (e.g. lerer 'teacher') and inflecting (e.g. tate 'father') nouns.

Table 1: Nominative, Accusative and Dative Case Inflection in Standard Yiddish

\begin{tabular}{|c|c|c|c|c|}
\hline & \multicolumn{3}{|c|}{ SINGULAR } & PLURAL \\
\hline & MASCULINE & FEMININE & NEUTER & \\
\hline NOMINATIVE & $\begin{array}{l}\text { der gut-er lerer } \\
\text { 'the good teacher' } \\
\text { der gut-er tate } \\
\text { 'the good father' }\end{array}$ & $\begin{array}{l}\text { di gut-e lererin } \\
\text { 'the good teacher' } \\
\text { di gut-e mame } \\
\text { 'the good mother' }\end{array}$ & $\begin{array}{l}\text { dos gut-e yingl } \\
\text { 'the good boy' } \\
\text { dos gut-e harts } \\
\text { 'the good heart' }\end{array}$ & $\begin{array}{c}\text { di gut-e lerer-s/ } \\
\text { tate-s/ } \\
\text { lererin-s/ } \\
\text { mame-s/ } \\
\text { yingl-ekh/ } \\
\text { herts-er }\end{array}$ \\
\hline ACCUSATIVE & $\begin{array}{l}\text { dem gut-n lerer } \\
\text { dem gut-n tat-n }\end{array}$ & $\begin{array}{l}\text { di gut-e lererin } \\
\text { di gut-e mame }\end{array}$ & $\begin{array}{l}\text { dos gut-e yingl } \\
\text { dos gut-e harts }\end{array}$ & $\begin{array}{c}\text { di gut-e lerer-s/ } \\
\text { tate-s/ } \\
\text { lererin-s/ } \\
\text { mame-s/ } \\
\text { yingl-ekh/ } \\
\text { herts-er }\end{array}$ \\
\hline DATIVE & $\begin{array}{l}\text { dem gut-n lerer } \\
\text { dem gut-n tat-n }\end{array}$ & $\begin{array}{l}\text { der gut-er lererin } \\
\text { der gut-er mame-(n) }\end{array}$ & $\begin{array}{l}\text { dem gutn yingl } \\
\text { dem gutn harts-(n) }\end{array}$ & $\begin{array}{c}\text { di gut-e lerers/ } \\
\text { tates/ } \\
\text { lererins/ } \\
\text { mames/ } \\
\text { yinglekh/ } \\
\text { hertser }\end{array}$ \\
\hline
\end{tabular}

As seen in Table 1, Yiddish exhibits a high degree of case syncretism, lacking any morphological distinction between (i) accusatives and datives in the masculine gender,

which largely reflect the grammatical system of Central and Southeastern Yiddish, are widely adhered to (Peltz 2003: 440).

${ }^{6}$ With the noun harts, the presence versus absence of the nominal inflection distinguishes the metaphorical and ordinary use of the word: fun dem likbtikn hartsn/?? harts 'from the heart filled with light' versus fun dem infitsirtn harts/? hartsn 'from the infected heart'. 
(ii) nominatives and accusatives in the feminine and neuter genders, and (iii) nominatives, accusatives and datives in plural nouns of all genders. ${ }^{7}$

In addition to the case forms given in Table 1, nouns may appear with the formative $-s$, which is sometimes described as marking genitive case (Birnbaum 1918: 35, 1939: 39; Joffe 1964: 21; Jacobs, Prince \& van der Auwera 1994: 402; Lincoff 1963: 48; Lockwood 1995: 9; Harbert 2007: 104), but more frequently as indicating 'possessive' (Mazin \& Woolf 1927: 10; Mark 1941: 50, 1978: 178; Birnbaum 1979: 224; Weissberg 1988: 126-27; Neuberg 1999: 56; Kiefer 2000: 1404; Aptroot \& Nath 2002: 110; Jacobs 2005: 161), due to its appearance in prenominal possessor constructions, such as (2).

$$
\begin{aligned}
& \text { a lerer-s bukh } \\
& \text { a teacher-s book } \\
& \text { 'a teacher's book' }
\end{aligned}
$$

Yiddish $-s$ is commonly ascribed to derive from the German stock language (Birnbaum 1939: 39; Weinreich 2008: 508, 654), corresponding to Middle High German -(e)s, the genitive marker on masculine and neuter nouns of the strong declension (Paul 2007: 185-86). Given the apparent etymological link between Yiddish $-s$ and the German genitive case marker $-(e) s$, the question arises why Yiddish grammarians have not uniformly analysed $-s$ as a genitive suffix, and, consequently, describe Yiddish to have a system of three rather than four morphological cases. The answer to this question may lie in two observations:

(i) The formative $-s$ has restricted syntactic distribution, occurring productively only in prenominal possessor constructions. ${ }^{8}$ If $-s$ was the exponent of genitive, genitive case in Yiddish would not serve the same range of functions that are found in other languages (cf. for example, the genitive case-marking of verbal, prepositional and adjectival complements in German). ${ }^{9}$

(ii) Yiddish definite determiners do not possess a formally distinct genitive form. If the formative $-s$ was a genitive case suffix, genitive case in Yiddish would be marked only on the noun, which is at odds

\footnotetext{
${ }^{7}$ In non-standard varieties of Yiddish, case distinctions in the nominal paradigm have been further eroded. For example, in both Northeastern (Lithuanian) and Central (Polish) Yiddish dialects, the accusative and dative have coalesced in the feminine gender, resulting in a single nominative-accusative-dative form (Wolf 1969: 129), while in contemporary (particularly spoken) Yiddish, there appears to be progressive levelling of all case distinctions (Jacobs 2005: 292).

${ }^{8}$ Possessive $-s$ may be found postnominally in Yiddish patronymic/matronymic constructions, such as, for example, Khane Leybs 'Hannah, Leyb's daughter' or Yitskhok Bashevis 'Isaac, Basheve's son'. While the construction is productive, it is limited to the merger of two names, the second of which may include an apposition, as in Motl Peysi dem khazns 'Motl, the cantor Peysi's son'. I will set aside patronymic/matronymic constructions in this article.

${ }^{9}$ See Fleischer \& Schallert (2011: 83-4), Scott (2011) and the articles by Ackermann and Gallmann in this volume concerning the actual use of genitive in contemporary German.
} 
with the generalisation that 'articles retain distinct case forms more robustly than nouns' (Harbert 2007: 105).

The first observation concerns the fact that Determiner Phrases (DPs) marked with $-s$ are found only in prenominal possessor phrases and do not occur nonadnominally. As shown below, Yiddish verbs cognate to verbs taking genitive objects in German $(\mathrm{G})$ appear with accusative objects or prepositional-phrase (PP) complements (cf. (3)-(4)); Yiddish prepositions, unlike their German counterparts, uniformly govern the dative (cf. (5)); and Yiddish adjectives corresponding to German adjectives that require genitive objects have PP-complements (cf. (6)).
a. Europa gedenkt des
Erst-en
Weltkrieg-s. Europe remembers the.M.SG.GEN first-M.SG.GEN world.war-GEN ${ }^{10}$ 'Europe remembers World War I.'

b. Eyrope gedenkt di ersht-e velt-milkhome. Europe remembers the.F.SG.ACC first-F.SG.ACC world-war

(4) a. Niemand bedient sich des gleich-en Vokabular-s. [G] nobody serves REFL the.N.SG.GEN same-N.SG.GEN vocabulary-GEN. 'Nobody uses the same vocabulary.'

b. Keyner badint zikh nisht nobody serves REFL not mit dem zelbik-n vokabular.
with the.M.SG.DAT same. M.SG.DAT vocabulary
a. anstatt des
Geld-es
instead the.N.SG.GEN money-GEN 'instead of the money'
b. anshtot dem gelt instead the.N.SG.DAT money
a. schuldig des Mord-es
guilty the.M.SG.GEN murder-GEN 'guilty of murder'
b. shuldik in dem mord guilty in the.M.SG.DAT murder

If $-s$ expressed genitive case in Yiddish, genitive case in Yiddish would be used exclusively to mark an adnominal relation in the domain of possession, which notwithstanding the fact that the structural marking of possession is regarded as the core function of the genitive - is cross-linguistically unusual, given the heterogeneity of functions characteristically performed by the genitive (for an overview, see Lander 2009 and Carlier \& Verstraete 2013).

The second observation refers to definite possessor phrases marked with $-s$ appearing with the determiner dem if the head noun is masculine or neuter (see $(7 \mathrm{a}, \mathrm{c})$ ), and der if the head noun is feminine (see (7b)).

\footnotetext{
10 The abbreviations used in the interlinear glosses follow the 'Leipzig glossing rules' (https://www.eva.mpg.de/lingua/resources/glossing-rules.php): M: masculine; F: feminine; N: neuter; SG: singular; PL: plural; GEN: genitive; ACC: accusative; DAT: dative; REFL: reflexive; DIM: diminutive.
} 

a. dem gutn lerer-s bukh
(masculine possessor)
the good teacher-s book
'the good teacher's book'
b. der guter lererin-s bukh
(feminine possessor)
the good teacher-s book
c. dem gutn kind-s bukh
the good child-s book
(neuter possessor)

The determiners dem and der are also used to mark oblique or dative case (cf. Table 1). What is more, modifying adjectives in the possessor phrase (e.g. gut- 'good' in (7)) will take the same case ending as adjectives in a DP marked for dative case, so that the (putative) dative/genitive distinction is signalled only by the noun marked with $-s$. While case syncretism is common in the Yiddish case paradigm, it is, at least within Germanic, typologically unusual that a morphologically marked case distinction should persist without the determiner continuing to reflect that case distinction (Harbert 2007: 105, Krifka 2009: 141).

In view of these two observations, Yiddish grammars and textbooks frequently describe prenominal possessor marking as involving the addition of 'possessive $-s$ ' to a possessor DP that is case-marked for dative, as reflected in the glosses in (8).
a. $\quad[$ dem
gut-n
lerer]-s bukh
[the.M.SG.DAT good-M.SG.DAT teacher]-s book 'the good teacher's book'
b. [der gut-er lerer-in]-s bukh
[the.F.SG.DAT good-F.SG.DAT teacher-F]-s book 'the good (female) teacher's book'
c. [dem gut-n kind]-s bukh [the.N.SG.DAT good-N.SG.DAT child]-s book 'the good child's book'

If Yiddish prenominal possessor DPs bear dative case, $-s$ cannot straightforwardly be analysed as a genitive case affix, which explains the approach to characterise this element in terms of its (possessive) function rather than its (case) form.

While generally understanding possessive $-s$ not to be a case marker, the Yiddish grammatical literature recognises some occurrences of $-s$ to be a 'rare vestige of genitive case' (Herzog et al. 2000: 344). These vestiges involve the optional presence of $-s$ in adverbial and partitive phrases, as exemplified in (9).
a. $\quad \operatorname{tsu} \operatorname{morgn}(\mathrm{s})$
to morning
'the next morning'
b. far tog(s)
before day
'at the crack of dawn'
c. a shtik veg(s)
a part way
'part of the way'

Vestigial genitives are also claimed to exist in the pronominal system (Birnbaum 1979: 249, fn. 97; Herzog et al. 2000: 140), able to surface, for example, as the complement of 
the periphrastic verb poter vern 'to get rid of' (which can alternatively occur with a prepositional complement, $\mathrm{cf}$. (10b)).
a. me darf zayner/irer poter vern
one must he.GEN/she.GEN free become
'One must get rid of him/her.'
b. me darf poter vern fun im/ir
one must free become from he.DAT/she.DAT
'One must get rid of him/her.'

In summary, the commonly accepted picture concerning morphological case and the expression of adnominal possession in Yiddish is as follows:

- Yiddish has three morphological cases: nominative, accusative and dative.

- While Yiddish possesses some vestigial genitive forms in the nominal and pronominal domains, it lacks productive genitive marking (including in adnominal constructions).

- Prenominal possessors bear dative case and are marked with an additional possessive element $(-s)$.

Whether considered from a synchronic or diachronic perspective, the established view raises various questions. These questions relate to, on the one hand, the morphosyntactic status of the possessive formative, and, on the other, the evidence for genitive in the older stages of Yiddish, which will be discussed in turn in the following sections.

\section{The Morphosyntactic Status of the Yiddish Possessive Marker}

\subsection{Prenominal Possessor Constructions in Fribourg German}

The curious double-marking of Yiddish prenominal possessors, which appear to bear dative case as well as a possessive marker, shows parallels with prenominal possessive constructions in other Germanic varieties. One such variety is the Alemannic dialect of Fribourg German (FG), in which simple possessor DPs are formed by combining a dative determiner with a noun marked with $-s$ (which is realised as a voiceless postalveolar fricative when preceded by /r/), cf. (11).

$$
\begin{aligned}
& \text { a. dum tokxtər-š wägeli } \\
& \text { the.M.SG.DAT doctor-s carriage } \\
& \text { 'the doctor's carriage' } \\
& \text { (Henzen 1927: 179) } \\
& \text { b. dər muətər-š lumpə } \\
& \text { the.F.SG.DAT mother-s headscarf } \\
& \text { 'the mother's headscarf } \\
& \text { (Henzen 1927: 179) }
\end{aligned}
$$

In the literature (Weiß 2008, Georgi \& Salzmann 2011), German dialectal doubly marked possessive constructions like (11) have been analysed as a variety of prenominal possessor doubling constructions, which are widely attested across German dialects 
(Fleischer \& Schallert 2011: 85). ${ }^{11}$ In possessor doubling constructions, exemplified in (12)-(13) with data from Fribourg and Colloquial German (CollG), a DP-possessor occurs with a possessive pronoun that shows agreement with both the possessor (in the stem) and the possessum (in the suffix).

$$
\begin{aligned}
& \text { dum tokxtər sis wägeli } \\
& \text { the.M.SG.DAT doctor his[N.SG.NOM] carriage } \\
& \text { 'the doctor's carriage' } \\
& \text { (Henzen 1927: 179) }
\end{aligned}
$$

a. dem Hund sein
the.M.SG.DAT dog his[N.SG.NOM] food
'the dog's food'
dem Hund sein-e L Leine
the.M.SG.DAT dog his-F.SG.NOM lead
'the dog's lead'

While their respective proposals differ in the details of the postulated phrase structure, both Weiß (2008: 5) and Georgi \& Salzmann (2011: 2082-83) claim that prenominal possessor DPs occupy the specifier of the possessive DP, whereas the doubled pronoun or possessive marker occurs in D. Dialectal doubly marked possessive constructions (as in FG) and prenominal possessor doubling constructions (as in both FG and CollG) are thus given the same structural analysis. ${ }^{12}$ As for the dialectal possessive marker $-s$, both accounts consider it to be a clitic, with 'genitive morphology presumably no longer genitive' (Weiß 2008: 3) but similar to English “"s”" (Georgi \& Salzmann 2011: 2079). ${ }^{13}$

Leaving aside the issue of whether clitics constitute a 'genuine category in grammatical theory' (Zwicky 1994: xiii) and, more generally, the question of how the relation between morphology and syntax is to be construed, ${ }^{14}$ there is universal consensus that the label 'clitic' points to 'an element which shares some of the features of an independent function word and some of the features of an affix' (Spencer \& Luís 2013: 124-25). More specifically, clitics are understood to differ from full forms in requiring a host with which they must fuse phonologically. They are understood to differ from (word-level) affixes by attaching to the edge of a phrase rather than to a particular

${ }^{11}$ Zifonun (2005: 46) seems to have in mind a similar analysis for Yiddish prenominal possessive marking when citing Yiddish as possible supporting evidence for the ability of possessive pronouns to develop into dependent affixes.

${ }^{12}$ See Roehrs (2013) for a different analysis of possessor doubling constructions, according to which the doubled pronoun is a composite form, consisting of a possessive element and an indefinite article; that is, German sein 'his' decomposes into s- + ein.

${ }^{13}$ The question whether English possessive -' $s$, which is placed at the right edge of a phrase but shows morphophonological interaction with its host word, should in fact be treated as a clitic has been subject of much debate. See Anderson (2013) for an overview.

${ }^{14}$ See, for example, Gerlach \& Grijzenhout (2000: 8-10) and Spencer \& Luís (2012: 327) on the status of clitics; and Harley (2015) and Fábregas \& Scalise (2012: 133-142) on theories of the morphosyntactic interface. 
type of word, showing a low degree of selection with respect to the host (Zwicky \& Pullum 1983: 503).

Weiß's and Georgi \& Salzmann's analyses of the FG possessive marker as a clitic then predict that FG $-s$ is found at the edge of the possessor DP, irrespective of (i) the type of possessor, (ii) the presence of any modifiers accompanying the possessor noun, or (iii) the syntactic category of whatever element occurs at the edge of the possessor phrase. This prediction is not fully borne out. As the examples in (14) show, FG possessive $-s$ is indeed not restricted to any particular type of possessor, but can occur with full singular and plural possessor DPs, including those modified by a possessive determiner.

a. min-um miitli-s maa
my-F.SG.DAT girl-s husband
'my girl's husband'
(Henzen 1927: 179)
b. $\quad$ pəōro-s hīmətlənı
the.PL.DAT farmers-s estates
'the farmers' estates'
(Henzen 1927: 179)

$[\mathrm{FG}]$

[FG]

However, FG possessive $-s$ is not found at the rightmost edge of a post-modified possessor DP. In other words, FG, unlike English, does not allow 'group genitives' of the structure $\left[[[\mathrm{NP}][\mathrm{PP}]]-s\right.$ Possessum], cf. (15a). ${ }^{15}$ Instead, complex possessors produce 'split genitives' ([[NP]-s Possessum [PP]]), where the possessive marker has combined with the head noun of the possessor DP and the post-modifying PP is extraposed to the right of the possessum, cf. (15b).
a. $\quad *$ dum
tokxtər us Bärn-s Auto
the.M.SG.DAT doctor from Bern-s car
b. dum tokxtər-šs Auto us Bärn
the.M.SG.DAT doctor-s car from Bern
'the car of the doctor from Bern'

FG prenominal possessor doubling constructions give rise to different grammaticality judgments on group and split genitives. As illustrated in (16), group genitives are perfectly possible in the possessor doubling construction, whereas split genitives are judged to be unacceptable.
a. dum
tokxtər us Bärn sis
Auto
the.M.SG.DAT doctor from Bern his[N.SG.NOM] car 'the car of the doctor from Bern'
b. *dum tokxtər sis Auto us Bärn the.M.SG.DAT doctor his[N.SG.NOM] car from Bern

Table 2 summarises the descriptive generalisation.

\footnotetext{
${ }^{15}$ The term 'group genitive' goes back to the work of Jespersen (1894: 279, 309-15); see Denison, Scott \& Börjars (2010: 536-37) for a brief discussion of its origin and historical definition.
} 
Table 2: Group and Split Genitives in FG Possessive Constructions

\begin{tabular}{|l|c|c|}
\hline & $\begin{array}{c}\text { Doubly Marked Possessive } \\
\text { Constructions }\end{array}$ & $\begin{array}{c}\text { Prenominal Possessor } \\
\text { Doubling Constructions }\end{array}$ \\
\hline $\begin{array}{l}{[[[\mathrm{NP}][\mathrm{PP}]]-s \text { Possessum] }} \\
\text { ('group genitive') }\end{array}$ & $*$ & $\checkmark$ \\
\hline $\begin{array}{l}{[[\mathrm{NP}]-s \text { Possessum [PP]] }} \\
\text { ('split genitive') }\end{array}$ & $\checkmark$ & $*$ \\
\hline
\end{tabular}

Two points emerge from the data in (15)-(16). First, the observed asymmetry between doubly marked possessive and prenominal possessor doubling constructions with respect to the acceptability of group and split genitives raises some doubt concerning Weiß's (2008) and Georgi \& Salzmann's (2011) claims that the two construction types have the same syntactic structure and that the FG possessive marker $-s$ is a variant of the possessive pronoun, with both originating in the D-head of the possessive DP. If there was no structural distinction between doubly marked possessive and prenominal possessor doubling constructions, it is not clear why the two construction types differ in the licensing of group and split genitives. ${ }^{16}$

Second, the variety of possessive constructions found in FG involving possessors post-modified by PPs parallel those attested in many historical Germanic varieties, as, for example, Swedish. ${ }^{17}$ Norde (2013) argues for the Swedish $-s$ genitive (as illustrated in farfar-s hem, 'grandpa's home') to have evolved from an inflectional affix to a clitic, ${ }^{18}$ which can no longer be appropriately described as a case marker. Crucially, she considers split genitives in Old Swedish (e.g. konungen-s stalmestare $i$ Danmark, lit. 'the king's equerry in Denmark', i.e. 'the king of Denmark's equerry'; Norde 2013: 321, ex. (28b)) to involve

${ }^{16}$ Bayer (2015: 5, fn. 5) makes a similar point in the context of observing that in (Colloquial) German, a universal quantifier is acceptable with a dative possessor in the possessor doubling construction (contra Haider 1992: 315), cf. (i), but not with a prenominal possessor marked with $-s$, cf. (ii):

(i)

$$
\begin{aligned}
& \text { alle der Maria ihre Bücher } \quad \text { [CollG] } \\
& \text { all-PL.NOM the.F.SG.DAT Mary her-PL.NOM books } \\
& \text { 'all Mary's books' } \\
& \text { (Bayer 2015: 4, ex. (4a)) }
\end{aligned}
$$

(ii) *alle Maria-s Bücher ...

$[(\mathrm{Coll}) \mathrm{G}]$

all-PL.NOM Mary-s books

(Bayer 2015: 3, ex. (1b))

As he notes, the difference between (i) and (ii) is difficult to account for in an analysis in which $-s$ is treated as an allomorph of the possessive pronoun, such as Krause (1999).

${ }^{17}$ See also Allen (2008) on the development of genitive constructions in the history of English, and Börjars, Denison, Krajewski \& Scott (2013) for a discussion of split genitives in present-day spoken English.

${ }^{18}$ See Börjars (2003) for an alternative view, according to which the Modern Swedish $-s$ genitive is not a clitic but a phrasal affix. 
word- or phrase-level affixation rather than enclitic marking. What sets apart affixal from clitic phrase-marking is the degree of selection: 'still quite selective about the word it attaches to', the $-s$ genitive in Old Swedish is unable to combine with 'word classes that are not inflected for case' (Norde 2013: 316). If, following Norde (2013) and others (see Allen 2008: 43), group genitives provide a diagnostic for the clitic status of a bound possessive marker, it must be the case that $\mathrm{FG}-s$ does not qualify as a clitic.

Note that Norde (2013: 318) recognises some of the inflected possessors in Old Swedish split genitive constructions (e.g. konungen-s in konungen-s stalmestare i Danmark, lit. 'the king's equerry in Denmark') to have phrasal rather than word-level affixation, given the lack of word-internal inflection and/or case agreement within the NP. ${ }^{19}$ The development of the Swedish $-s$ genitive in this period may hence be characterised as 'a change from genitive case being an agreement feature to it being a once only feature, generally marked on the head noun' (Börjars 2003: 144). Whether the FG possessive $-s$ can similarly be described as a once-only marker is less clear since the determiner in the FG possessor DP is overtly marked for case, albeit not one that is self-evidently identifiable as genitive.

The notion of phrasal affix draws attention to the separability of placement and degree of attachment in the description of affixes and clitics, as explicated by Börjars (2003). While phrasal affixes are placed with respect to a phrase, they are morphologically attached to (and hence selective about) a word. In Börjars's (2003: 141) view, the distinction between clitic and affix is not binary but forms part of a continuum, which can be conceptualised along three dimensions, mapped in Figure 1: (i) once-only marking vs. agreement, (ii) edge vs. head placement, and (iii) syntactic vs. morphological attachment.

Figure 1: Potential Variation in Exponence of Noun Phrase Features (Börjars 2003: 141)

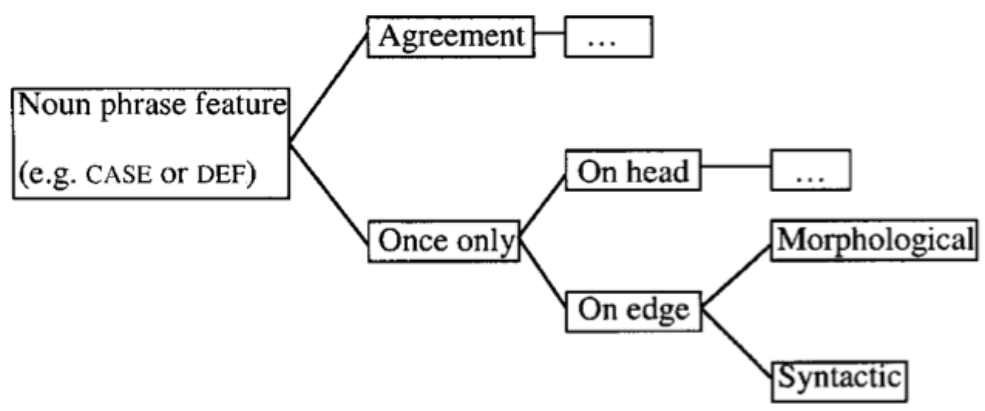

Languages thus vary along the following lines: first, morphosyntactic features like case or definiteness can be marked once or on various heads throughout the nominal phrase; second, if a feature is marked just once, it can appear either on the edge of a phrase or on a (nominal) head; third, if it appears on the edge of a phrase, there may or may not be morphophonological interaction between the marker and its host. Of relevance to the present study, Börjars's three-dimensional distinction sets out a clear stepwise procedure for investigating the morphosyntactic status of possessive marking.

To sum up, the extant analyses of FG doubly marked possessive constructions face two shortcomings: (i) they subsume doubly marked possessive constructions under

\footnotetext{
${ }^{19}$ Old Swedish definite nouns showed case inflection on both the noun and the bound definite article (Norde 2013: 315), so that word-level inflection of the possessor DP konung-en 'the king' for genitive case would have produced *konung-s-en-s.
} 
prenominal possessor doubling, leaving unexplained why complex possessor phrases do not behave identically in the two construction types; (ii) they analyse possessive $-s$ as a clitic, which predicts the availability of group genitives, contrary to fact. While further analysis of FG possessive structures is beyond the scope of this article, the FG data provide a useful point of comparison against which to consider the properties of Yiddish prenominal possessives. More specifically, the data, when viewed in the context of Börjars's (2003) framework for describing variation in the exponence of morphosyntactic features, identify the following questions:

- Are prenominal possessors limited to certain DPs (e.g. animate nouns)?

- Is the possessive marker a once-only marker (or do nominal modifiers of the possessor bear concordial marking)?

- Is the possessive marker able to appear in group genitives, attaching 'promiscuously' to words of any category?

\subsection{The Properties of Yiddish Prenominal Possessors}

Using the questions set out in the previous section, the present discussion of the properties of Yiddish prenominal possessors first considers what types of nominals can occur as possessors, and then turns to the empirical evidence for once-only occurrence and edge placement of possessive $-s$.

\subsubsection{Selectional Restrictions}

In Standard Yiddish, both proper nouns and full DPs, which can include definite, possessive or indefinite determiners as well as adjectival phrases, can occur as prenominal possessors:
a. Dovid-s (nay-e) shikh
David-s new-PL shoe.PL
'David's (new) shoes'
b. dem yingl-s (nay-e) shikh
the boy-s new-PL shoe.PL
'the boy's (new) shoes
c. mayn yingl-s (nay-e) shikh
my boy-s new-PL shoe.PL
'my boy's (new) shoes
d. a yingl-s (nay-e) shikh
a boy-s new-PL shoe.PL
'a boy's (new) shoes'

Alternatively, a possessor can be realised as a PP in post-possessum position, in which case it is introduced by fun 'of, from', and, like all prepositional complements, casemarked for dative, cf. (18).
a. di shikh fun Dovid-n
the.PL shoe.PL of David-SG.DAT
'David's shoes'
b. di shikh fun dem/ mayn/a yingl 
the.PL shoe.PL of the.N.SG.DAT/my /a boy

'the/my/a boy's shoes'

Prenominal possessors are prototypically [+ animate]; non-animate possessors are largely confined to occurring in post-possessum position (Mark 1978: 179; Birnbaum 1979: 224).
a. dem yingl-s fus
the boy-s foot/leg
'the boy's foot/leg'
b. dem hintl-s fus the dog.DIM-s foot/leg
c. *baym barg-s fus at.the.M.SG.DAT mountain-s foot/leg
d. baym fus fun barg
at.the.M.SG.DAT foot/leg of mountain
'at the foot of the mountain'

For many speakers, prenominal possessors can only be [+ singular] (Birnbaum 1918: 34; Lincoff 1963: 36; Mark 1978: 179; Weinreich 1981: 131, 325; Lockwood 1995: 110; Gold 2009: 649, fn. 10). Some speakers also accept [+ plural] prenominal possessors marked with possessive $-s$, although acceptability is degraded for possessor nouns whose plural marker is $-s$ (e.g. zeyde, 'grandfather'), cf. (20). ${ }^{20}$
a. $\quad \% \ldots$ zol oysgeyn tsu soyn-im-s kep
... should go-out to enemy-PL-s head.PL
'[It] should go on my enemies' heads.'
(Weissberg 1988: 129)
b. *?beyde zeyde-s yikhes-briv
both grandfather-PL/s pedigree-letter.PL
(Gold 2009: 649, fn. 10)
c. di yikhes-briv fun beyde zeyde-s
the.PL pedigree-letter.PL of both grandfather-PL
'both grandfathers' family trees'
(Gold 2009: 649, fn. 10)

In summary, the possessive marker $-s$ is found without exception on [ + animate, + singular] proper and common nouns in prenominal possessor position. Dialectal variation exists with respect to the possessive marking (and, consequently, occurrence in prenominal possessor position) of $[+$ animate, + plural $]$ nouns.

${ }^{20}$ In singular nouns ending in /s/, the possessive marker goes unexpressed, e.g. (i).

(i) dem balebos' zun

the owner- $\varnothing$ son

'the owner's son'

This appears not to be possible for plural nouns in the varieties allowing prenominal plural possessors, since otherwise it is not clear why plural noun phrases like beyde zeydes, 'both grandfathers', in (20b) are not licensed in prenominal position. 


\subsubsection{Morphological Marking}

Prenominal possessors show only a single instance of the possessive formative $-s$, used regardless of the gender of the head noun (cf. (8)), and occurring to its immediate right. This is clearly seen in the examples in (21), which contain the proximate and distal demonstratives (ot) $d$ - 'this' (which is essentially homophonous with the definite article) and yen- 'that'. Where the demonstrative stands alone as a possessor, it is affixed with $-s$ (cf. (21a)); where it modifies a noun, it is the noun that carries the possessive marker (cf. (21b)). Affixation of $-s$ to both the demonstrative and the noun gives rise to ungrammaticality, as seen in (21c).
a. (ot) dem-s/ yen-em-s bukh this.M.SG.DAT-s that-M.SG.DAT-s book 'this/that one's book'
b. (ot) dem/ yen-em lerer-s bukh this.M.SG.DAT that-M.SG.DAT teacher-s book 'that teacher's book'
c. * (ot) dem-s/ yen-em-s lerer-s bukh this.M.SG.DAT-s / that-M.SG.DAT-s teacher-s book

As standardly assumed in the Yiddish grammatical literature (cf. section 2), and reflected in the glosses for (21) and (22), $-s$ appears to attach to a possessor marked for dative; that is, definite possessor DPs show the determiner, pronominal and adjectival endings which also appear in DPs that are unambiguously dative, such as prepositional complements:
a. $\quad$ der
yingst-er
tokhter-s shtub
the.F.SG.DAT youngest-F.SG.DAT daughter-s house 'the youngest daughter's house'
b. mit der yingst-er tokhter with the.F.SG.DAT youngest-F.SG.DAT daughter 'with the youngest daughter'

But when it comes to the marking of inflecting nouns as possessors, the form of the possessor noun does not always equate to dative + possessive $-s .{ }^{21}$ Masculine and neuter nouns that can take the dative case suffix $-n$ occur with the possessive marker outside the case affix - irrespective of whether the noun is obligatorily (cf. (23a)) or optionally (cf. $(23 \mathrm{~b}, \mathrm{c}))$ inflected for dative:
a. dem tat-n-s shtub
the father-SG.DAT-s house
'the father's house'

\footnotetext{
${ }^{21}$ This is not true for all speakers. There is textual evidence (see, for example, Rozenfarb 1947: 33) for forms like der mamens ('the mother's'), which has the dative suffix $-n$ in a feminine possessor noun (see also Kiefer 2000: 1404). Vice versa, some varieties use possessor forms that lack any dative marking, as, for example, in dem zeydes ('the grandfather's'; see Gold (2009: 649, fn. 10). For the native speakers consulted here, only the forms presented in the main text reflect natural usage.
} 
b. dem yid-n-s shprakh

the Jew-SG.DAT-s language

'the Jew's language'

c. dem harts-n-s bager

the. heart-SG.DAT-s desire

'the pure heart's desire'

In contrast, the possessor form of proper names and the three feminine nouns that can inflect for dative (mame, 'mother'; bobe, 'grandmother'; mume 'aunt') does not contain the dative suffix but only the possessive marker $-s$, as illustrated in (24)-(25).
a. Dovid-s trer-n
David-s tear-PL
'David's tears'
b. bay Dovid-n
with David-SG.DAT
'with David'
c. *Dovid-n-s trern
David-SG.DAT-s tear-PL
(25) a. der mame-s trer-n
the mother-s tear-PL
'the mother's tears'
b. bay der mame-n
at the mother-SG.DAT
'with the mother'
c. *der mame-n-s trern
the mother-SG.DAT-s tear-PL

If the possessive marker $-s$ attached to a possessor DP fully marked for dative, it is forms like ${ }^{*}$ Dovidns and * mamens that are predicted to occur rather than the attested Dovids ('David's') and mames ('mother's'), given that possessive $-s$ and dative noun inflection cooccur in masculine and neuter common nouns like tatns ('father's'). If, as the possessors

Dovids and mames might suggest, possessive marking attached to an uninflected possessor noun, it is tatns, yidns ('Jew's') and hartsns ('heart's') in (22) that remain unexplained.

To sum up, there is no evidence for multiple occurrences of possessive $-s$ in Yiddish prenominal possessor phrases. On the other hand, it is far from clear that possessor DPs lack concordial genitive case marking since closer inspection reveals possessor noun phrases not to decompose uniformly into a dative-marked DP followed by $-s$, contrary to the accepted view. Given the high degree of case syncretism in Yiddish, it can thus not be excluded that determiners and adjectival endings which have the appearance of dative are in fact exponents of genitive case, and are hence indicative of internal case agreement in the possessor phrase.

\subsubsection{Type of Placement}

As discussed above, group genitives provide a reliable test for establishing whether a once-only marker is placed at the head or on the edge of a possessor phrase. Examples of complex possessor phrases that potentially occur in the group genitive construction encompass (i) coordinated possessors, (ii) possessors with a post-modifying PP, and 
(iii) possessors post-modified by a relative clause. Type (i) is absent in the majority standard variety of Yiddish, given the proscription against plural possessors in prenominal position. ${ }^{22}$ Trying to use Type (ii) possessors in the group genitive construction results in unacceptable structures, as illustrated in (26a). ${ }^{23}$ Note that, unlike in FG, Type (ii) possessors do not permit split genitive constructions, cf. (26b), and the only way to realise a possessive with a complex possessor is for the possessor to occur in postnominal position, as shown in (26c).
a. $\quad *$ dem rov fun der
ortik-er
shul-s
tokhter
the rabbi of the.F.SG.DAT local-F.SG.DAT synagogue- $s$ daughter
b. * dem rov-s tokhter fun der
ortik-er
shul
the rabbi-s daughter of the.F.SG.DAT local-F.SG.DAT synagogue
c. di tokhter funem rov fun der ortik-er shul
the daughter of.D.M.SG.DAT rabbi of the.F.SG.DAT local-F.SG.DAT synagogue 'the daughter of the local synagogue's rabbi'

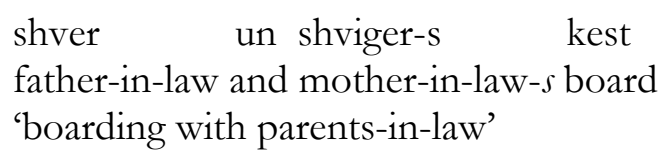

${ }^{22}$ In varieties that permit prenominal plural possessor phrases, group genitives appear at first sight possible, as, for example, in the following line from a Yiddish folksong:

On the other hand, shver un shviger may not be a coordinated noun phrase but instead a fixed combination equivalent to a plural noun, as suggested by data like (ii), in which the phrase combines with the plural definite article $d i$.

(ii) ...di shver un shviger zoln nit visn the.PL father-in-law and mother-in-law should not know '...the parents-in-law should not know'

(Sholem Aleichem 1917-1923: 4.213)

If so, (i) does not constitute a true group genitive but may be more aptly analysed as the occurrence of a plural possessor in prenominal position.

${ }^{23}$ There are complex possessors which allow phrase-final positioning of $-s$, e.g. (i)-(ii).

(i) Shloyme ha-melekh-s khokhme

Solomon the-king-s wisdom

'King Solomon's wisdom'

(ii) dem raboyne-shel-oylem-s tanoyim

the lord-of-world-s Tannaim

'the Lord's Rabbinic sages'

However, these are examples of proper names, and as such 'do not demonstrate a general ability of the possessive marker to attach to the end of a complex phrase' (Allen 2008: 51). 
Possessors post-modified by a relative clause similarly fail to give rise to group or split genitives and are similarly limited to post-possessum position, as exemplified in (27).
a.
*dem rov vos hot a gel-e
bord-s tokhter
the rabbi that has a yellow-F.SG.ACC beard- $s$ daughter
b. *dem rov-s tokhter vos hot a gel-e bord ${ }^{24}$
the rabbi-s daughter that has a yellow-F.SG.ACC beard
c. di tokhter funem rov vos hot a gel-e bord the daughter of.D.M.SG.DAT rabbi that has a yellow-F.SG.ACC beard 'the daughter of the rabbi who has a red beard'

In sum, Yiddish provides no evidence for the possessive marker to attach at the right edge rather than the head of the possessor DP since post-modified possessors are generally absent from prenominal position.

\subsection{Summary and Analysis}

This section's survey of the morphosyntactic properties of Yiddish prenominal possessor phrases has yielded the following facts:

- re Once-only marking vs. agreement:

Animate, singular possessor DPs in prenominal position bear a single instance of possessive $-s$.

All elements of the possessor DP are overtly inflected for case (which is not the same as dative).

- re Edge- vs. head-marking

Possessive $-s$ attaches to the head noun, which must be situated at the right edge of the possessor phrase.

- re Syntactic vs. morphological attachment

On the assumption that possessive DPs do not in fact bear dative case, the possessive marking found on head nouns has variant exponence, occurring as

(i) -s; (ii) -ns (as in tatns, 'father's', cf. (23)); and (iii) - $\varnothing$ (as in balebos', 'owner's', cf.

(i) in fn. 20, Section 3.2.1)).

Taken together, these points suggest that the possessive marker $-s$ does not show the characteristics of a true clitic but, in line with a scalar approach to morphosyntactic categories, is more 'affix-like'. First, $-s$ is not straightforwardly analysable as a once-only marker. Second (even if it were a once-only marker), the unacceptability of group genitives rules out an analysis of $-s$ as an element that is subject to 'pure' right-edge, nonhead placement. Third (even if it were attached at the phrase level), the presence of lexically and phonologically triggered variants of $-s$ argues in favour of morphological rather than syntactic attachment, assuming that 'morphophonological idiosyncracies are more characteristic of affixed words than of clitic groups' (Zwicky \& Pullum 1983:

504). ${ }^{25}$ Accordingly, if, as in Börjars's (2003) approach, the most-clitic like element on the

\footnotetext{
${ }^{24}$ The phrase in $(27 \mathrm{~b})$ is grammatical if the relative clause is interpreted as a modifier of the possessum (tokhter, 'daughter').

${ }^{25}$ But see Nevins (2011: 959), who argues that 'in reality it is very hard to find a clitic that
} 
clitic-affix continuum is a once-only marker placed at the edge with an attachment that is syntactic in nature, whereas the most affix-like element is a marker associated with concordial agreement, the evidence concerning Yiddish possessive $-s$ points towards the affix end of the continuum.

The data presented in this section further show that in both FG and Yiddish the right edge of the possessor phrase coincides with the head noun. Yiddish thus does not have possessives of the type found in formal written Swedish (illustrated in (28a)), where a complex possessor occurs in prenominal position but the possessive marking is attached to the head noun rather than the right edge of the DP:
a.
institution-en-s för slaviska språk prefekt department-DEF-s for Slavonic languages head-of-department 'the Head of the Department of Slavonic languages'
(Börjars 2003: 149, ex. (16a))
b. *dem rov-s fun der ortik-er shul tokhter the rabbi-s of the local-F.SG.DAT synagogue daughter

In the view of Börjars (2003: 150), the occurrence of the Swedish $-s$ genitive in both group genitives and constructions like (28a) indicates that the marker is subject to conflicting constraints concerning type of placement; that is, it is required to appear, on the one hand, on the right edge of the noun phrase and, on the other hand, on the head noun. The constraints conflict can be resolved by avoiding complex possessors in prenominal position altogether, either by rendering the complex possessor as a PPcomplement to the possessum, or, as in older forms of Swedish, by extraposition of the post-modifier.

These very strategies also seem to be employed by Yiddish and FG speakers, with the former opting for prepositional constructions in the post-possessum position, and the latter able to make use of split genitives. It may then be the case that the Yiddish and FG possessive markers, like the Swedish $-s$ genitive, face conflicting pressures due to being involved in diachronic change from head- to edge-marking. Yiddish dialectal variation concerning the distribution and expression of possessive marking (cf. the extension of possessive marking to plural nouns, discussed in Section 3.2.1; and the occurrence of uniform stem + suffix structures with inflecting nouns discussed in fn. 21, Section 3.2.2) lends some support to the idea that Yiddish $-s$ has been in the process of acquiring properties more typical of phrasal than word-level inflection. The fluidity afforded by conceptualising the clitic-affix distinction as continuous rather than dichotomous is then well suited to the description of Yiddish -s. All the same, concerning the morphosyntactic status of the Yiddish possessive marker, the conclusion must stand that possessive $-s$ has not (yet) reached the clitic end of the clitic-affix continuum.

\section{Some Remarks on the Diachrony of Yiddish Possessive Marking}

As previously stated, Yiddish possessive $-s$ is understood to derive from the Middle High German (MHG) genitive ending of strong masculine and neuter nouns (Birnbaum 1939: 39; Weinreich 2008: 508, 654)). German possessive constructions in the MHG period (1050-1350) could take various forms: not only did prenominal genitives exist alongside postnominal ones, with the latter gradually becoming entrenched as the unmarked

does not show some degree of allomorphy, making this diagnostic restrictive to the point where, if it is literally followed, perhaps nothing can be a clitic at all'. 
variant (Scott 2014: 218), but there is also evidence for possessor doubling constructions (Lockwood 1968: 21; Koptjevskaja-Tamm 2003: 665) and the emergence of analytical structures involving the preposition von ('of') (Behaghel 1924: 62). Whether assuming the 'classic' Rhineland hypothesis (Weinreich 2008: 1-45) or a more easterly origin of Yiddish (as proposed by, among others, Katz 1987b and Wexler 1987), the scenario generally agreed upon is that Yiddish developed between 'the end of the Old High German [OHG] period and the early part of the MHG period - somewhere between the ninth and twelfth centuries' (Jacobs 2005: 13) ${ }^{26}$ If so, Yiddish arose in a context in which it would have been exposed to multiple possessive constructions through language contact with its stock language German.

This section considers evidence concerning the expression of possession in the Middle Yiddish period (1500-1750), and suggests a possible diachronic account of the development of Yiddish possessive marking. The discussion is based on the work of Neuberg (1999), who investigates stylistic phenomena in the Yiddish 'women's bible' Tsenerene. The Tsenerene (whose title derives from the phrase tse'enab u-re'enab benot Tsiyon, 'Go forth and look, daughters of Zion', in verse 3:11 of the Song of Songs) is a Yiddish adaptation of the biblical books that are part of Jewish liturgical life, combined with Midrashic narrative material. It was composed around 1600 by Yankev ben Yitskhok Ashkenazi of Janów, with the two oldest extant editions dating from 1622 (Hanau) and 1648 (Amsterdam). ${ }^{27}$ It is these editions that are used in Neuberg's (1999) study.

Like all Yiddish printed books prior to the end of the eighteenth century, the Tsenerene employs a literary language based on Western Yiddish which sought to avoid regionalisms so as to reach (and be marketable to) all potential readers throughout the Yiddish speech territory (Kerler 1999: 17-18). Neuberg (1999: 109) further observes that the two editions provide evidence of diverse written dialects ('Schreibdialekte') by displaying lexical variation, but claims that syntactic variation in this period is impossible to delimit, whether geographically or temporally.

\subsection{Prenominal Possessors in the Tsenerene}

In the Tsenerene, prenominal possessor phrases occur in a variety of forms (Neuberg 1999: 48-57): $:^{28}$ (i) prenominal possessor DPs with concordial genitive morphology, e.g.

\footnotetext{
${ }^{26}$ See Beider (2015: 1-10) for a summary of the different theories of the origins of Yiddish, as well as an exposition of his own divergent view that Yiddish has a more recent (fifteenth-century) origin and that the two main dialects (Western and Eastern Yiddish) share no common ancestor.

${ }^{27}$ The Tsenerene is the most popular Yiddish book of all times, published in more than 210 editions and reprinted to the present day; see Elbaum \& Turniansky (2010) for further information.
}

${ }^{28}$ The Tsenerene further provides evidence for the use of postnominal possessives, which have the same format as in modern Yiddish, cf. (i).

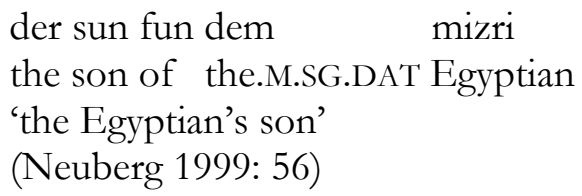


(29); (ii) prenominal possessor DPs with 's-omission' (a term borrowed from Scott 2014 : 221), which involve a determiner marked for genitive but no affix on the noun itself, e.g. (30); (iii) determinerless possessors with possessive -s, e.g. (31); (iv) prenominal possessor DPs with no dependent marking, e.g. (32); and (v) possessor doubling constructions, e.g. $(33) \cdot{ }^{29}$

(29) Prenominal possessor DPs with concordial genitive morphology
a. des man-s
the.M.SG.GEN man-M.SG.GEN
'the man's'
b. des mensch-en
the.M.SG.GEN human-M.SG.GEN
'the human's'
c. des khaver-s
the.M.SG.GEN friend-s
'the friend's'
d. des weib-s
the.N.SG.GEN wife-N.SG.GEN
'the wife's'
e. des herz-en
the.N.SG.GEN heart-N.SG.GEN
'the heart's'

(30) Prenominal possessor DPs with 's-omission'
a. des man
the.M.SG.GEN man
'the man's'
b. des khaver
the.M.SG.GEN friend
'the friend's'

(31) Determinerless possessors with possessive $-s$
a. meler-s
'miller's'
miller-M.SG.GEN
b. muter-s
mother-s
'mother's'
c. kind-s
child-N.SG.GEN
'child's'

(32) Prenominal possessor DP with no dependent marking

ain melech sun

a.M.SG.NOM king son

'a king's son'

\footnotetext{
${ }^{29}$ The data in this section are presented as transcribed by Neuberg (1999), who follows the Trier conventions for the transcription of older Yiddish (see Neuberg 2000: 2-4).
} 


$$
\begin{aligned}
& \text { Possessor doubling construction } \\
& \text { ain-es malach sein kol } \\
& \text { a-M.SG.GEN angel his voice } \\
& \text { 'an angel's voice' }
\end{aligned}
$$

The various possessive constructions found in the Tsenerene can be traced back to the different stock languages of Yiddish (viz. German, Hebrew-Aramaic, Romance and Slavic), but also illustrate the 'fusional' character of Yiddish, in which elements deriving from different strata combined in a new system (cf. Weinreich 2008: 29). First, prenominal possessors with concordial marking, possessors with possessive $-s$ and possessor doubling constructions straightforwardly correspond to structures found in the MHG and Early New High German (ENHG; 1350-1650) varieties coterritorial with Yiddish. The phenomenon of $s$-omission, too, is encountered in German since the MHG period (Behaghel 1923: 480; Scott 2014: 215). For prenominal possessors with no dependent marking on either the determiner or noun (cf. (32)), Neuberg (1999: 55-56) hypothesises that these are Yiddish innovations modelled on the Hebrew construct-state construction. Used to encode possessive relations, the Hebrew construct-state construction juxtaposes two nominals: the possessum in the so-called construct state (which is usually, but not always, morphologically marked) precedes the possessor in the unmarked absolute state, e.g. sefer ha-kohen, lit. 'book the-priest', i.e. 'the priest's book' (Futato 2003: 70); (Bathsheba) bat Eliam, lit. '(Bathsheba) daughter Eliam', i.e. (Bathsheba), Eliam's daughter'. In the Yiddish adaptation of this construction, which occurs predominantly with patronyms, the 'construct' noun appears to be able to either precede or follow the 'absolute', as seen, respectively, in sun Eloser, 'son of Eleazar' and Jizhok sun (wor 'Éśev), 'the son of Isaac (was Esau)' (Neuberg 1999: 55-56).

Second, the possessive data demonstrate the fusion of the different components since prenominal possessors with a German-origin, genitive-marked determiner (with or without $s$-omission on the noun) are found not only with German-derived nouns but also with those of Hebrew-Aramaic origin, such as khaver in (29c) and (30b) and malach, 'angel', in (33). The occurrence of nouns from the Hebrew-Aramaic component in possessive constructions in which the head noun is morphologically marked is noteworthy, given Lincoff's (1963: 35) observation that until the late Middle Yiddish period (i.e. before the seventeenth century), 'Hebrew nouns show absolutely no [German-origin] case inflections' (see also Timm 1987: 368), although the lack of inflection is likely to have been 'merely an orthographic omission, not reflecting actual usage'.

The data in (29) and (33) further illustrate that in the period of the Tsenerene, Yiddish still had distinct genitive singular forms of the definite and indefinite determiner (des, aines) as well as different inflectional endings for masculine and neuter nouns corresponding to German nouns of the 'strong' and 'weak' declensions, cf. $-s$ in mans in (29a), vs. -en in menschen in (29b) and berzen in (29e). ${ }^{30}$ The possessor forms in (31) show the genitive case ending of strong masculine and neuter nouns to attach to masculine and

\footnotetext{
${ }^{30} \mathrm{It}$ is well known that written language is generally more conservative than spoken language. Textual evidence may therefore provide a skewed picture of the diachronic development. Nevertheless, written language may be assumed to represent variants that existed in the spoken language either at the time of writing or at an earlier time, so that changes in the written language document those in the spoken language, even if the written record may lag behind speech (for a development of this argument, see Curzan 2003: 55).
} 
neuter one-word noun phrases (meler, 'miller'; kind, 'child'), but, crucially, also to the feminine one-word noun phrase muter ('mother'). The extension of $-s$ to single-word, feminine prenominal possessors may coincide in timing with the same development in ENHG: as Scott (2014: 237-8) notes, German possessive -s, which is limited to determinerless proper names and kinship terms in prenominal position, emerged 'at least by the mid-seventeenth century', gaining in popularity throughout the eighteenth and nineteenth centuries.

In summary, the possessive data supplied by Neuberg's (1999) study of the Tsenerene allows the following generalisations:

- Seventeenth-century Yiddish, as reflected in the Tsenerene, had morphologically distinct genitive case forms for (German-origin) determiners and nouns.

- The inflectional element $-s$ had become productive, spreading from strong masculine and neuter nouns of German origin to feminine nouns and nouns belonging to the Hebrew-Aramaic component.

- Prenominal possessor nouns were not consistently inflected: $s$-omission could affect both German- and Hebrew-origin nouns, and occurred in possessors with and without inflected determiners.

\subsection{A Diachronic Scenario}

While the language of the Tsenerene exhibits a considerably greater degree of inflection on determiners and nouns than modern Yiddish, the text also shows that the loss of the genitive, masculine/neuter definite determiner des was already under way. Neuberg (1999: 51) observes that des appears in variable spellings, frequently rendered as שאד (das/dos = the neuter nominative/accusative singular form of the definite article) rather than the שעד (des). These misspellings suggest that genitive determiners no longer formed part of the active competence of seventeenth-century Yiddish speakers, and that the text preserved morphosyntactic patterns with which the typesetters were not familiar. ${ }^{31}$

The loss of genitive case morphology on determiners that manifests itself in the Tsenerene was preceded by apocope, which resulted in the loss of the genitive marker $-e$ on feminine strong nouns of the German component (Timm 1999: 23). The process, dated by Weinreich (2008: 519) to have been completed before the Middle Yiddish period (see also Lincoff 1963: 44; Timm 1987: 218), gave rise to feminine possessors without any dependent marking (see Timm 1999: 23, who gives the example of Bele tochter, 'Bella's daughter'). The emergence of such unmarked feminine possessors may have contributed to masculine possessor DPs with no dependent marking changing syntactic position from postnominal position (which conforms to the ordering of possessum and possessor in the Hebrew construct-state construction) to prenominal position, as in Jizhok sun ('Isaac's son') or ain melech sun ('a king's son', cf. (32)).

Timm (1999: 23) further comments on the affixation of $-s$ to feminine proper name possessors (e.g. Haves, 'Chava's'), which is attested as early as the late sixteenth century, proposing that feminine possessors with $-s$ developed on the model of the possessive marking of diminutives of female names. Like all diminutives, hypocoristics

\footnotetext{
${ }^{31}$ Cf. Kerler (1999: Parts I \& II), who discusses various cases of morphosyntactic conservatism in eighteenth-century re-editions of Old Yiddish texts.
} 
(e.g. Tsorlin, 'little Sarah'; Weinreich 2008: 614) are of neuter gender, and hence required $-s$ in the genitive singular. The use of $-s$ may then have spread from diminutive female names to non-diminutive female names and, in a further development, to feminine nouns, such as muter ('mother', cf. (31b)).

In summary, Old and Middle Yiddish texts up to and including the Tsenerene provide evidence for three diachronic developments affecting the marking of prenominal possessors:

(i) the loss of genitive marking on feminine strong nouns (by the $16^{\text {th }}$ century);

(ii) the analogical extension of the masculine/neuter genitive suffix $-s$ to feminine (proper) nouns in prenominal possessor position (by the late $16^{\text {th }}$ century);

(iii) the loss of genitive marking on masculine/neuter determiners (by the early $17^{\text {th }}$ century).

When considering the further diachronic development in the period from the seventeenth century to Modern Standard Yiddish, what needs to be accounted for is the replacement of des by dem as the definite article in masculine and neuter possessor DPs, as well as the fact that some, but not all, inflecting nouns appear to have the dative singular suffix $-n$ when occurring as possessors. To understand how the process that yielded the synchronic outcome might have unfolded, it is helpful to review what is known about the organisation of nominal inflection in pre-modern Yiddish.

Lincoff (1963: 29-51) charts the changes in case morphology during the Old, Middle and Modern Yiddish periods. For Old Yiddish, she assumes, as in MHG, a distinction between strong and weak nouns, with masculine, feminine and neuter strong nouns having distinct case endings for both genitive $(-(e) s$ M./N.SG.GEN; $-e$ F.SG.GEN) and dative ( $-a$ M./N.SG.DAT; $-e$ F.SG.DAT) in the singular paradigm. Weak nouns of all genders were characterised by $-e n$ in the accusative, genitive and dative singular. By the Middle Yiddish period (1500-1750), apocope had eroded the morphological distinctions in the nominal system, obliterating the dative singular marking of masculine and neuter strong nouns, as well as the genitive and dative singular marking of feminine strong nouns. For weak nouns, Lincoff (1963: 48) suggests that the case endings were 'gradually dropped through the actions of analogy', and concludes that '[i]n late MY [Middle Yiddish] one can no longer speak of any nouns as being 'weak', since by analogy with strong nouns, nouns historically weak show no case inflection in the singular'.

Lincoff's account thus ignores (or at least does not grant any special status to) the nine inflecting nouns tate, 'father'; zeyde, 'grandfather'; rebe, '(traditional) rabbi, teacher'; yid, 'Jew, man'; mentsh, 'person'; mame, 'mother'; bobe, 'grandmother'; mume, 'aunt'; and harts, 'heart'. Four of these nouns came into Yiddish from MHG, where they belonged to the weak paradigm: yid < MHG jude, jüde (Weinreich 2008: 492); mentsh < MHG mensch(e), mume $<$ MHG muome, and harts $<$ MHG hërze. The nouns tate and mame, while often claimed to be of Slavic origin, may also derive from the German component (see Beider 2015: 168), with both tate and mamme attested as weak nouns in MHG (for tate, see Lexer 1992: 2:1408; for mamme, see Lexer 1992: 1:2021 and Gärtner et al. 1992: 233). This leaves the nouns zeyde, bobe and rebe: while zeyde and bobe are of Slavic origin, ${ }^{32}$ rebe derives from Hebrew / rabi/ and, according to Weinreich (2008: 486), is possibly 'the oldest extant evidence of fusion' in Yiddish, having undergone umlaut at a time when umlaut

\footnotetext{
${ }^{32}$ Beider (2015: 431) suggests an Old Czech origin for both terms.
} 
was a regular phonological process in German. Like tate and mame, zeyde, bobe and rebe are disyllabic trochees ending in schwa, designating family or close social relationships. In short, what unites the class of Yiddish nouns inflected for case is their origin as, or (in the case of zeyde, bobe and rebe) their phonological and semantic similarity to, German weak nouns.

In German, weak nouns evolved from a class that, in MHG, encompassed nouns of all three genders to one confined to masculine nouns which prototypically denote male animates and are (or, alternatively, end in) syllabic trochees with a final schwa (Nübling 2008: 284). The diachronic change involved nouns of all three genders changing inflectional class, leading to a substantial reduction in the number of members of the weak noun class. MHG feminine weak nouns, such as zunge, 'tongue', coalesced with the (strong) feminine ô-stems nouns (e.g. gâbe, 'gift'). The shift of feminine nouns away from the class of weak nouns was characterised by two competing developments: (i) extension of the oblique case form across the singular sub-paradigm, e.g. MHG zunge$\varnothing$ (SG.NOM), zunge- $n$ (SG.GEN) > zungen- $\varnothing$ (SG.NOM), zungen- $\varnothing$ (SG.GEN); (ii) the loss of the oblique case inflection $-n$ throughout the singular, e.g. MHG zunge- $\varnothing$ (SG.NOM), zunge-n (SG.GEN) > zunge- $\varnothing$ (SG.NOM), zunge- $\varnothing$ (SG.GEN) (Hartweg \& Wegera 2005: 15253). It is the latter development that ultimately prevailed in the development to $\mathrm{NHG}^{33}$ although the process took its time, with singular forms ending in $-n$ persisting into the eighteenth century (Wegera \& Solms 2000: 1543).

In contrast, the shift of MHG masculine weak nouns into the strong inflection class involved both developments; that is, weak nouns could either simply lose their oblique case inflection (as, for example, MHG hane > NHG Hahn, 'rooster') or, if inanimate, undergo paradigm levelling, with the nominative changing to match the oblique case form (e.g. MHG tropfe > NHG Tropfen, 'drop'). For a small number of masculine nouns, the original weak noun and the levelled form co-exist in the contemporary language (e.g. Glaube/Glauben, 'belief'), with the genitive singular of the weak noun formed by means of an augmented genitive suffix -ns (e.g. Glaube-ns). The augmented suffix seemingly combines the weak and strong genitive marker, but a form like Glaubens may in fact stem from a morphological reanalysis of the genitive form of the strong noun Glauben, which assumed Glaube to be the base form of Glaubens so that the $n$ had to be interpreted as part of the inflectional affix.

As for the MHG neuter weak nouns (a sub-class composed of only four nouns, viz. bërre, 'heart'; ôre, 'ear'; ouge, 'eye'; and wange 'cheek'; Schmid 2009: 158), most members shifted directly to the strong paradigm, with no paradigm levelling taking place. ${ }^{34}$ The noun bërze (> NHG Herz), however, occupies a special position since it retains the weak inflectional marker $-(e) n$ in the singular paradigm (cf. Herz-en, 'heartSG.DAT') while forming the genitive singular by means of an augmented genitive suffix (Herz-ens).

The proposal made here is that, contrary to what is claimed in Lincoff (1963: 48), Yiddish, like German, preserved a declension class of weak nouns, which is characterised by suffixation with - ns in the genitive singular, and constituted by the inflecting masculine nouns (tate, 'father'; zeyde, 'grandfather'; rebe '(traditional) rabbi, teacher'; yid, 'Jew, man';

\footnotetext{
${ }^{33}$ Upper German varieties, on the other hand, are characterised by levelling of the oblique case form in the singular paradigm, cf. Bavarian Wiesn, 'lawn', and Zungn 'tongue' (Hartweg \& Wegera 2005: 153).

${ }^{34}$ In the case of wange, the change in inflectional class membership was accompanied by a change to feminine gender.
} 
mentsh, 'person') and the neuter noun harts 'heart'. ${ }^{35}$ The postulated genitive suffix -ns corresponds to the augmented genitive marker found in ENHG forms cognate with some of the Yiddish weak nouns, viz. Jüdens (von Zesen 1971: 213), Mynschens and Herzens (Wegera \& Solms 2000: 1543). As noted by Solms \& Wegera (1993: 171), augmented genitive suffixes started to appear with German animate weak nouns in the fifteenth century. Fairly widespread in the sixteenth and seventeenth centuries, their use waned in the development to NHG, which saw $-(e) n$ restored as the genitive singular marker. ${ }^{36}$ The gradual disappearance of the augmented genitive marker (and return to a single genitive ending for weak nouns) was possibly the outcome of linguistic prescription (Krischke 2012: 76-77). Given, on the one hand, the language contact that existed between Yiddish and German, and, on the other, the fact that Yiddish was not affected by the recommendations of classical German grammarians, it seems feasible that Yiddish adopted and retained the augmented genitive suffix for weak nouns.

Yiddish feminine inflecting nouns, which either derive from German weak nouns (mame, 'mother'; mume, 'aunt') or, as disyllabic trochees with the semantic feature [+human] (bobe, 'grandmother'), match the prototypical template for a weak noun, show 'mixed' properties: while they inflect with $-n$ in the dative singular just like weak nouns, they are not marked for the accusative singular and take $-s$ rather than the augmented genitive suffix -ns when occurring as prenominal possessors. The inflectional behaviour of these nouns receives an explanation if, as in German, these originally weak feminine nouns shifted out of the weak declension class, losing the characteristic $-(e) n$ inflection in the non-nominative cases, and (unlike in German) took on $-s$ inflection in the genitive singular. To account for the presence of $-n$ in the dative singular, it may be proposed that $-n$ in the dative singular was reintroduced to nouns (including proper nouns) denoting family and community members, in line with the 'clear tendency to maintain distinctive case marking for objects ranking high on the animacy hierarchy' (Albright \& Fuß 2012: 276).

The picture that then emerges is that Yiddish nouns can be classified into three declension classes, as depicted in Table 3.

Table 3: Yiddish Nominal Declension Classes

\begin{tabular}{|l|l|l|l|}
\hline & $\begin{array}{c}\text { Class 1 } \\
\text { (default class) }\end{array}$ & $\begin{array}{l}\text { Class 2 } \\
\text { (fem. inflecting } \\
\text { nouns; [+human] } \\
\text { proper nouns) }\end{array}$ & $\begin{array}{l}\text { Class 3 } \\
\text { (masc. \& neut. } \\
\text { inflecting nouns) }\end{array}$ \\
\hline NOM & $-\varnothing$ & $-\varnothing$ & $-\varnothing$ \\
\hline GEN & $-s$ & $-s$ & $-n s$ \\
\hline ACC & $-\varnothing$ & $-\varnothing$ & $-n$ \\
\hline DAT & $-\varnothing$ & $-n)$ & $-n$ \\
\hline
\end{tabular}

Class membership is predictable on the basis of gender, prosodic type and semantic properties: while disyllabic feminine close kinship terms ending in schwa and [+human]

${ }^{35}$ Unlike NHG weak nouns, however, Yiddish weak nouns are not indexed by the nominative plural form as, with the exception of yid and mentsh, they do not take an - $n$ suffix in the plural (cf. tate-s, 'father-PL'; hertser, hearts.PL').

${ }^{36}$ But see Krischke (2012), whose corpus study of non-standard genitive marking in Modern German shows forms like Menschens to persist. 
proper nouns make up Class 2, and masculine and neuter close kinship terms/terms of address form Class 3, Class 1 can be regarded as the default class, encompassing all other nouns. Both Class 2 and Class 3 have their origin in the class of MHG weak nouns; nouns belonging to Class 1 , on the other hand, pattern with the MHG strong masculine/neuter class in the realisation of their singular cases.

Understanding Yiddish to have maintained a system of declension classes, and, what is more, a distinct genitive case form, can then provide an answer to the question why some, but not all, inflecting nouns appear to have the dative singular suffix $-n$ when occurring as possessors. Far from decomposing into a dative form $+-s$ affix, Yiddish prenominal possessors are noun phrases marked for genitive case. Genitive case marking on the noun involves different allomorphs $(-s$ and $-n s)$, conditioned by declension class. The different genitive markers and declension classes have discrete historical roots, and reflect the transformations that occurred in the nominal systems of both Yiddish and German in the sixteenth and seventeenth centuries.

Concerning the question of what explains the replacement of des by dem as the definite determiner in masculine and neuter possessor DPs, Lincoff (1963: 54-55) offers the hypothesis that 'the analogical extension of dem to gen.sg. is perhaps due to the relative infrequence of gen.sg. in Mod[ern] Yiddish'. Taken together with the fact that in late Middle Yiddish, dem had replaced (or at least was in the process of replacing) the earlier masculine accusative definite article den (Kerler 1999: 73), Lincoff's statement may suggest that the extension of dem to the genitive singular was driven by paradigm uniformity constraints, since it resulted in a masculine determiner paradigm with only two distinct forms, viz. SG.NOM der and SG.GEN/ACC/DAT dem. The merger of dem and des in the neuter determiner paradigm similarly reduced the number of forms, with only SG.NOM/ACC dos and SG.GEN/DAT dem found in Modern Yiddish. However, here the merger did not create a single oblique form, and it may be questioned why it was dem rather than dos that was extended to the genitive singular. It is therefore worth considering in more detail the mechanisms by which the change from des to dem in both the masculine and neuter genders may have been effected.

Under the present proposal, the gateway to the modern Yiddish state of affairs was supplied by Class 3 nouns, marked as genitive with the augmented suffix -ns. Once new genitive forms, such as yid-ns, 'Jew- SG.GEN', came into the language, they could be interpreted not as containing an augmented genitive suffix $-n s$, but rather as the marker $-s$ having attached to a form affixed with dative $-n$. The 'resegmentation' and 'revaluation' (Fertig 2013: 27) of the morphological make-up of masculine and neuter genitive forms ending in -ns may have been aided by the identity of form between the OY (and MHG) weak genitive and dative singular adjective endings $(-(e) n)$, as well as the fact that the genitive feminine determiner der was, like its German cognate, syncretic with the dative form. Revaluation of - $n s$ as including dative inflection would have led to the replacement of the old genitive definite article des (already on its way out in the Tsenerene) with the dative definite article dem, thereby giving rise to possessor DPs of the type exemplified by dem khavers ('the friend's) and dem kinds ('the child's), in which what looks like a dative definite article combines with a masculine or neuter non-inflecting noun marked with $-s$.

However, revaluation of forms like yidns did not lead to dative-marked possessor forms of feminine inflecting nouns (i.e. * mame-n-s rather than mame-s) in the majority standard variety. This may suggest that revaluation was reversed in the majority variety; that is, while the masculine and neuter genitive determiners became syncretic with the dative, $-n s$ itself was reinterpreted as a unitary suffix, with forms like yidns derived from 
the nominative base form yid by a single process of affixation. ${ }^{37}$ Such resegmentation may have been motivated by four-part analogy: with the formative $-n$ being absent in the genitive form of feminine and proper nouns (even though it occurs in the dative of these nouns), possessors like der mames provide no supporting evidence for an analysis of -ns as an affix sequence, but suggest that possessors are created by means of a single affix (mame: der mame-s :: yid: dem yid-AFFIX).

In other, non-standard varieties (labelled here Dialects 1 and 2; cf. fn. 21), revaluation and four-part analogy yielded different outcomes. First, in Dialect 1, resegmentation and revaluation of -ns resulted in common noun possessors that can be uniformly decomposed into a dative noun phrase $+-s$, e.g. dem tat-n-s, the.M SG.DAT father-DAT-s'; der mame-n-s, 'the.F SG.DAT mother-DAT-s', with -s perhaps no longer constituting a genitive case suffix but a once-only marker of the syntactic dependency of the possessor on the possessum. In Dialect 2, four-part analogy resulted not in the reinterpretation of $-n s$ as a unitary affix, but rather in the analogical extension of $-s$ as genitive marker for all nouns. Dialect 2 thus has possessor forms like der tate-s, replacing earlier dem tat-ns.

Figure 2 charts the proposed paths of development for Yiddish possessor marking in all three varieties, viz. Standard Yiddish, Dialect 1 and Dialect 2.

Figure 2: Proposed Diachronic Paths of Development for Yiddish Possessor Marking

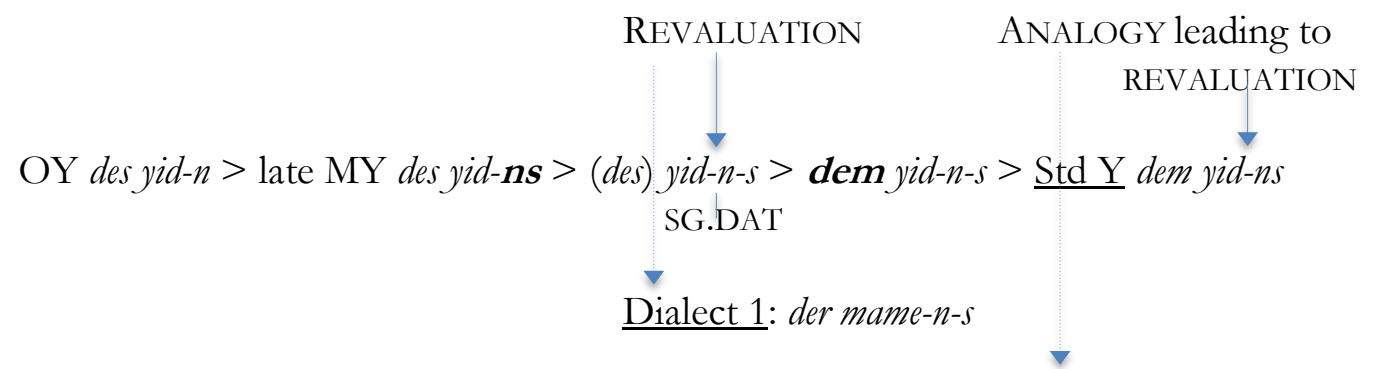

Dialect 2: dem yid-s, dem tate-s

In conclusion, the Middle Yiddish textual evidence suggests that the transition from Middle to Modern Yiddish was characterised by a range of developments, related to, and to some extent parallelling, the evolution of the German declension system in the ENHG period. More specifically, it is claimed here that the data allow the following observations and hypotheses:

- Apocope led to the loss of overt genitive marking on feminine strong nouns, which subsequently adopted $-s$ as exponent of genitive singular, thereby eliminating the distinction between strong masculine/neuter and feminine declension classes.

- The class of weak nouns became eroded, with only a small number of [+animate] masculine and neuter nouns remaining to be marked with a suffix derived from the genitive singular marker of the OHG $n$-stem class. The genitive singular affix attached to these nouns changed from -(e) $n$ to 'augmented' - $n s$, which, as it increased the distinctiveness of the case ending, may be considered an instance of 'syntagmatic profiling' (Kürschner \& Nübling 2011: 362).

\footnotetext{
${ }^{37}$ See Maiden (2016) for discussion of 'vacillation' in morphological (re-)segmentation of Romanian nominals. If vacillating segmentations are possible, resegmentation cannot be subject to unidirectionality but should be reversible.
} 
- A concomitant of the change in genitive marking for weak nouns was the resegmentation of $-n s$ as comprising the dative suffix $-n+-s$, which contributed to the loss of the Middle Yiddish genitive definite determiner des, and the appearance of the dative definite determiner dem in prenominal possessor DPs.

- Speakers of the majority standard variety reintroduced -ns as a weak genitive ending on the basis of analogy with the genitive forms of feminine inflecting nouns, which contain only a monosegmental affix $(-s)$.

\subsection{Summary}

The focus of this section has been the question how possessor DPs were realised in the Middle Yiddish editions of the Tsenerene, and what diachronic path can be reconstructed that leads from the Middle Yiddish textual evidence to contemporary usage in the standard variety.

As suggested by the evidence from the Tsenerene, Middle Yiddish had

- distinct genitive forms of indefinite and definite determiners (aines, des), even if their use may have been in decline;

- declension-class based genitive allomorphy $(-s,-e n)$;

- considerable variation in the realisation of prenominal possessors (as concerns the presence/absence of genitive marking on the head noun and the accompanying determiner).

The system of declension, already unstable and variable in seventeenth-century Middle Yiddish, underwent significant change in the late Middle Yiddish period. More specifically, it is postulated here that:

- membership of the declension class of weak nouns was reduced to only a handful of predominantly masculine, [+animate/+human] nouns;

- weak nouns developed a new, augmented genitive marker (-ns);

- case syncretism increased in the determiner domain, leading to the loss of the old accusative definite determiner den, but also the collapse of the distinction between genitive and dative definite determiners (which may have been a by-product of the morphological resegmentation and revaluation of the weak genitive marker $-n s$ ).

The central observation and claim made here concerns the class of inflecting nouns, for which it is argued that they either share an origin as MHG weak nouns or were included in this class on the basis of phonological and semantic properties (disyllabicity, trochaic foot structure, human denotation) that align them with the 'prototypically' weak noun (cf. Köpcke 1995). The common origin and distinctive characteristics of inflecting nouns suggest that Yiddish has maintained a distinction between strong and weak declension classes, contra Lincoff (1963).

\section{Conclusion}

As set out in the Introduction, the question whether Yiddish possessive marking is an instance of genitive case may be answered in the affirmative if (i) Yiddish is a language 
with morphological case; (ii) the possessive marker shows affixal properties; and (iii) the nominal to which the possessive marker attaches is not otherwise case-marked. This article argued that all three requirements are fulfilled.

With respect to (i), the traditional view has always been that Yiddish has a morphological case system, distinguishing nominative, accusative and dative in both the nominal and pronominal system. If we understand morphological case to involve alternations in the form of a noun phrase based on its grammatical function, the distinctions represented in the definite determiner and nominal paradigms given in Table 1 confirm this view.

As for (ii), when conceptualising the continuum between affixes and grammatical words along the distinctions of once-only marking vs. agreement, edge vs. head placement, and syntactic vs. morphological attachment (Börjars 2003: 141), there is sufficient evidence to characterise Yiddish possessive marking as affixal, since it cooccurs with (non-nominative/accusative/dative) case morphology in the possessor DP (i.e. Yiddish possessor phrases are not strictly marked 'only once'), attaches to a head noun (i.e. Yiddish does not license 'group genitives'), and exhibits variant phonological realisation (i.e. Yiddish possessor marking is not insensitive to the lexical nature of its host).

Finally, as concerns (iii), much of the argument made here for Yiddish possessive marking as a case of genitive has rested on the fact that the form a nominal takes in the possessive construction does not equate to a dative DP $+-s$, contrary to what is asserted in traditional grammars. More specifically, masculine and feminine nouns that optionally inflect for dative as well as proper nouns show the divergence between possessive and dative marking: while possessive marking of inflecting masculine nouns must involve the augmented suffix $-n s$, which seemingly contains the dative suffix $-n$ (e.g. yidns, *yids), the possessor form of proper names and the three inflecting feminine nouns can only have $-s$ (e.g. *Dovidns, Dovids; *mamens, mames). The alternation between $-n s$ and $-s$ in the marking of possessors can be accounted for as a pattern of (genitive) case allomorphy

conditioned by declension class; that is, nouns affixed with -ns belong to a separate class of predominantly masculine, [+animate/+human] nouns, directly traceable to the class of 'weak nouns' in Middle Yiddish. Along with the claim that Yiddish distinguishes a genitive case, this article thus suggests that Yiddish has retained a system of declension classes, albeit one in which the class of 'weak nouns' has eroded even further than in its stock language and relative, German. Taking into account the diachronic origin of Yiddish inflecting nouns allows an analysis of the synchronic facts of possessive marking which captures both the behaviour of the possessive formative as a case-marking affix and its variation in form. Accordingly, the case of Yiddish genitive provides an example of diachronic considerations contributing to a theoretical understanding of synchronic grammar.

\section{References}

Aikhenvald, Alexandra Y. 2002. Typological parameters of clitics, with special reference to Tariana. In R. M. W. Dixon \& Alexandra Y. Aikhenvald (eds.), Words: A crosslinguistic typology, 1-41. Cambridge: Cambridge University Press.

Albright, Adam \& Eric Fuß. 2012. Syncretism. In Jochen Trommer (ed.), The morphology and phonology of exponence, 236-287. Oxford: Oxford University Press.

Allen, Cynthia. 2008. Genitives in Early English: Typology and evidence. Oxford: Oxford University Press. 
Anderson, Stephen R. 2013. The marker of the English 'group genitive' is a special clitic, not an inflection. In In Kersti Börjars, David Denison, \& Alan Scott (eds.), Morphosyntactic categories and the expression of possession, 193-217. Amsterdam \& Philadelphia, PA: John Benjamins.

Aptroot, Marion \& Holger Nath. 2002. Einführung in die jiddische Sprache und Kultur. Hamburg: Buske.

Bayer, Josef. 2015. A note on possessor agreement. In Hiroki Egashira, Hisatsugu Kitahara, Kazuo Nakazawa, Tadao Nomura, Masayuki Oishi, Akira Saizen \& Motoko Suzuki (eds.), In untiring pursuit of better alternatives, pp. 2-11. Tokyo: Kaitakusha.

Behaghel, Otto. 1923. Deutsche Syntax: Eine geschichtliche Darstellung, vol.1: Die Wortklassen und Wortformen, A. Nomen, B. Pronomen. Heidelberg: C. Winter.

Behaghel, Otto. 1924. Deutsche Syntax: Eine geschichtliche Darstellung, vol.2: Die Wortklassen und Wortformen, B. Adverbium, C. Verbum. Heidelberg: C. Winter.

Beider, Alexander. 2015. Origins of Yiddish dialects. Oxford: Oxford University Press.

Birnbaum, Salomo A. 1918. Praktische Grammatik der jiddischen Sprache für den Selbstunterricht. Wien \& Leipzig: A. Hartleben.

Birnbaum, S. 1939. The age of the Yiddish language. Transactions of the Philological Society 38.1, 31-43.

Birnbaum, S. A. 1979. Yiddish: A survey and a grammar. Toronto: University of Toronto Press.

Blake, Barry J. 2001. Case (2 ${ }^{\text {nd }}$ edn.). Cambridge: Cambridge University Press.

Börjars, Kersti. 2003. Morphological status and (de)grammaticalisation: The Swedish possessive. Nordic Journal of Linguistics 26.2, 133-163.

Börjars, Kersti, David Denison, Grzegorz Krajewski \& Alan Scott. 2013. Expression of possession in English: The significance of the right edge. In Kersti Börjars, David Denison, \& Alan Scott (eds.), Morphosyntactic categories and the expression of possession, 123-148. Amsterdam \& Philadelphia, PA: John Benjamins.

Carlier, Anne \& Jean-Christophe Verstraete. 2013. Genitive case and genitive constructions: An introduction. In Anne Carlier \& Jean-Christophe Verstraete (eds.), The genitive, 1-16. Amsterdam \& Philadelphia, PA: John Benjamins.

Chomsky, Noam. 1981. Lectures in Government and Binding: The Pisa lectures. Dordrecht: Foris.

Curzan, Anne. 2003. Gender shifts in the history of English. Cambridge: Cambridge University Press.

Denison, David, Alan K. Scott \& Kersti Börjars. 2010. The real distribution of the English "group genitive". Studies in Language 34.3, 532-564.

Elbaum, Jacob \& Chava Turniansky. Tsene-rene. 2010. In Gershon Hundert (ed.), The YIVO encyclopedia of Jews in Eastern Europe, vol. 2, 1912-13. New Haven, CT: Yale University Press.

Embick, David \& Rolf Noyer. 2001. Movement operations after syntax. Linguistic Inquiry 32.4, 555-595.

Fábregas, Antonio \& Sergio Scalise. 2012. Morphology: From data to theories. Edinburgh: Edinburgh University Press.

Fertig, David. 2013. Analogy and morphological change. Edinburgh: Edinburgh University Press.

Fillmore, Charles J. 1968. The case for case. In Emmon Bach \& Robert T. Harms (eds.), Universals of linguistic theory, 1-90. New York: Holt, Rinehart \& Winston.

Fishman, J. A. 2001. A decade in the life of a two-in-one language: Yiddish in New York City (secular and ultra-orthodox). In Joshua A. Fishman (ed.), Can threatened languages be saved?, 74-100. Clevedon: Multilingual Matters. 
Fishman, Joshua A. 2008. Language: Planning and standardization of Yiddish. In Gershon Hundert (ed.), The YIVO encyclopedia of Jews in Eastern Europe, vol. 1, 987-991. New Haven, CT: Yale University Press.

Fleischer, Jürg \& Oliver Schallert. 2011. Historische Syntax des Deutschen: Eine Einführung. Tübingen: Narr.

Futato, Mark David. 2003. Beginning Biblical Hebrew. Winona Lake, IN: Eisenbrauns.

Gärtner, Kurt, Christoph Gerhardt, Jürgen Jaehrling, Ralf Plate, Walter Röll \& Erika Timm. 1992. Findebuch zum mittelhochdeutschen Wortschatæ. Stuttgart: Hirzel.

Georgi, Doreen \& Martin Salzmann. 2011. DP-internal double agreement is not double Agree. Lingua 121.14, 2069-2088.

Gerlach, Birgit \& Janet Grijzenhout. 2000. Clitics from different perspectives. In Birgit Gerlach \& Janet Grijzenhout (eds.), Clitics in phonology, morphology and syntax, 1-29. Amsterdam \& Philadelphia, PA: John Benjamins.

Gold, David L. 2009. Studies in etymology and etiology: With emphasis on Germanic, Jewish, Romance, and Slavic languages. Alicante: Universidad de Alicante.

Haider, Hubert. 1992. Die Struktur der Nominalphrase: Lexikalische und funktionale Strukturen. In Ludger Hoffmann (ed.), Deutsche Syntax: Ansichten und Aussichten, 304-333. Berlin: De Gruyter.

Harbert, Wayne. 2007. The Germanic languages. Cambridge: Cambridge University Press.

Harley, Heidi. The syntax-morphology interface. 2015. In Tibor Kiss \& Artemis Alexiadou (eds.), Syntax - theory and analysis: An international handbook, vol. 2, 11281154. Berlin: Mouton de Gruyter.

Hartmann, Katharina \& Malte Zimmermann. 2002. Syntactic and semantic adnominal genitive. In Claudia Maienborn (ed.), (A)symmetrien - (a)symmetries: Beiträge zu Ehren von Ewald Lang, 171-202. Tübingen: Stauffenburg.

Hartweg, Frédéric \& Klaus-Peter Wegera. 2005. Frübneubocbdeutsch: Eine Einfübrung in die deutsche Spraches des Spätmittelalters und der frühen Neuzeit ( $2^{\text {nd }}$ edn.). Tübingen: Niemeyer.

Haspelmath, Martin. 2009. Terminology of case. In A. L. Mal'chukov \& Andrew Spencer (eds.), The Oxford handbook of case, 505-17. Oxford: Oxford University Press.

Haspelmath, Martin. 2011. The indeterminacy of word segmentation and the nature of morphology and syntax. Folia Linguistica 45.1, 31-80.

Henzen, Walter. 1927. Die deutsche Freiburger Mundart im Sense- und südöstlichen Seebezirk. Frauenfeld: Huber.

Herzog, Marvin, Vera Baviskar, Ulrike Kiefer, Robert Neumann, Wolfgang Putschke, Andrew Sunshine \& Uriel Weinreich (eds.). 2000. The Language and culture atlas of Ashkenaric Jewry, vol. 3: The Eastern Yiddish - Western Yiddish continuum. Tübingen: Niemeyer.

Jacobs, Neil G. 2005. Yiddish: A linguistic introduction. Cambridge: Cambridge University Press.

Jacobs, Neil G., Ellen F. Prince \& Johan van der Auwera. 1994. Yiddish. In Ekkehard König \& Johan van der Auwera (eds.), The Germanic languages, 388-419. London: Routledge.

Jespersen, Otto. 1894. Progress in language: With special reference to English. London: Sonnenschein.

Joffe, Judah A. 1964. Der genitiv in yidish. Yidishe shprakh 24.2, 19-23.

Katz, Dovid. 1987a. Grammar of the Yiddish language. London: Duckworth.

Katz, Dovid. 1987b. The proto-dialectology of Ashkenaz. In Dovid Katz (ed.), Origins of the Yiddish language, 47-60. Oxford: Pergamon Press.

Kerler, Dov-Ber. 1999. The origins of modern literary Yiddish. Oxford: Clarendon Press. 
Kiefer, Ulrike. 2000. Das Jiddische in Beziehung zum Mittelhochdeutschen. In Werner Besch, Anne Betten, Oskar Reichmann \& Stefan Sonderegger (eds.), Sprachgeschichte: Ein Handbuch zur Geschichte der deutschen Sprache und ibrer Erforschung ( $2^{\text {nd }}$ edn.), vol. 2, 1399-1408. Berlin \& New York: de Gruyter.

Köpcke, Klaus-Michael. 1995. Die Klassifikation der schwachen Maskulina in der deutschen Gegenwartssprache - ein Beispiel für die Leistungsfähigkeit der Prototypentheorie. Zeitschrift für Sprachwissenschaft 14.2, 159-180.

Koptjevskaja-Tamm, Maria. 2003. Possessive noun phrases in the languages of Europe. In Frans Plank (ed.), Noun phrase structure in the languages of Europe, 621-722. Berlin: Mouton de Gruyter.

Krause, Cornelia. 1999. Two notes on prenominal possessors in German. MIT Working Papers in Linguistics 33, 191-217.

Krifka, Manfred. 2009. Case syncretism in German feminines: Typological, functional and structural aspects. In Patrick Steinkrüger \& Manfred Krifka (eds.), On inflection, 141-172. Berlin: Mouton de Gruyter.

Krischke, Wolfgang. 2012. Des Menschens Genitive. Linguistik Online, 53.3.

Kürschner, Sebastian \& Damaris Nübling. 2011. The interaction of gender and declension in Germanic languages. Folia Linguistica 45.2, 355-388.

Lander, Yury. A. 2009. Varieties of genitive. In Andrej Mal'chukov \& Andrew Spencer (eds.), The Oxford handbook of case, 581-592. Oxford: Oxford University Press.

Lexer, Matthias. 1992. Mittelhocdeutsches Handwörterbuch, 3 vols. Leipzig: Hirzel.

Lincoff, Beatrice. 1963. A study in inflectional morphologic development. Old and Middle Yiddish. Ph.D. dissertation, New York University.

Lockwood, W. B. 1968. Historical German syntax. Oxford: Clarendon Press.

Lockwood, W. B. 1995. Lehrbuch der modernen jiddischen Sprache. Hamburg: Buske.

Maiden, Martin. 2016. Ambiguity in Romanian word structure: The structure of plurals in ....uri. Revue roumaine de linguistique 61.1, 3-12.

Mark, Yudl. 1941. Folk(s)lid, leben(s)frayd, tsaytung(s)mentsh: vegn dem samekh in di tsunoyfheftn. Yidishe shprakb 1.2, 47-56.

Mark, Yudl. 1978. Gramatik fun der yidisher klal-shprakh. New York: Alveltlekher yiddisher kultur-kongres.

Mazin, J. \& S. De Woolf. 1927. A manual and grammar of the Yiddish language. London: R. Mazin.

Mlotek, Chana \& Mark Slobin (eds.). 2007. Yiddish folksongs from the Ruth Rubin archive. Detroit: Wayne State University Press.

Neuberg, Simon. 1999. Pragmatische Aspekte der jiddischen Sprachgeschichte am Beispiel der ZZenerener. Hamburg: Buske.

Neuberg, Simon. 2000. Das schwedesch lid: Ein westjiddischer Bericht über die Ereignisse in Prag im Jahre 1648. Hamburg: Buske.

Nevins, Andrew. 2011. Multiple Agree with clitics: Person complementarity vs. omnivorous number. Natural Language and Linguistic Theory 29.4, 939-971.

Norde, Muriel. 2013. Tracing the origins of the Swedish group genitive. In Anne Carlier \& Jean-Christophe Verstraete (eds.), The genitive, 299-332. Amsterdam \& Philadelphia, PA: John Benjamins.

Nübling, Damaris. 2008. Was tun mit Flexionsklassen?: Deklinationsklassen und ihr Wandel im Deutschen und seinen Dialekten. Zeitschrift für Dialektologie und Linguistik 75.3, 282-330.

Paul, Hermann. 2007. Mittelhochdeutsche Grammatik ( $25^{\text {th }}$ edn.), rev by Thomas Klein, Hans-Joachim Solms \& Klaus-Peter Wegera. Tübingen: Niemeyer. 
Peltz, Rakhmiel. 2003. Yiddish: A language without an army regulates itself. In Ana Deumert \& Wim Vandenbussche (eds.), Germanic standardizations: Past to present, 431-454. Amsterdam \& Philadelphia, PA: John Benjamins.

Roehrs, Dorian. 2013. Possessives as extended projections. Working Papers in Scandinavian Linguistics 91, 37-112.

Rozenfarb, Khava. 1947. Di balade fun nekbtikn vald un andere lider. London: The Narod Press.

Schmid, Hans Ulrich. 2009. Einfübrung in die deutsche Sprachgeschichte. Stuttgart: Metzler.

Scott, Alan K. 2011. Everyday language in the spotlight: The decline of the genitive case. German as a Foreign Language 1, 53-70.

Scott, Alan K. 2014. The genitive case in Dutch and German: A study of morphosyntactic change in codified languages. Leiden: Brill.

Sholem Aleichem. 1917-1923. Ale verk fun Sholem Aleykhem (28 vols.). New York: Sholom Aleykhem folksfond oysgabe.

Solms, Hans-Joachim \& Klaus-Peter Wegera. 1993. Flexionsmorphologie. Oskar Reichmann \& Klaus-Peter Wegera (eds.), Frübneubochdeutsche Grammatik, 164-312. Tübingen: Niemeyer.

Spencer, Andrew \& Ana R. Luís. 2012. Clitics: An introduction. Cambridge: Cambridge University Press.

Spencer, Andrew \& Ana Luís. 2013. The canonical clitic. In Dunstan Brown, Marina Chumakina \& Greville G. Corbett (eds.), Canonical morphology and syntax, 123-150. Oxford: Oxford University Press.

Taylor, John R. 1996. Possessives in English: An exploration in Cognitive Grammar. Oxford: Oxford University Press.

Timm, Erika. 1987. Graphische und phonische Struktur des Westjiddischen unter besonderer Berücksicbtigung der Zeit um1600. Tübingen: Niemeyer.

Timm, Erika. 1999. Matronymika im aschkenasischen Kulturbereich: Ein Beitrag zur Mentalitätsund Sozialgeschichte der europäischen Juden. Tübingen Niemeyer.

Wegera, Klaus-Peter \& Hans-Joachim Solms. 2000. Morphologie des Frühneuhochdeutschen. In Werner Besch, Anne Betten, Oskar Reichmann \& Stefan Sonderegger (eds.), Sprachgeschichte: Ein Handbuch zur Geschichte der deutschen Sprache und ihrer Erforschung (2 ${ }^{\text {nd }}$ edition), vol.2, 1542-1554. Berlin: De Gruyter.

Weinreich, Max. 2008. History of the Yiddish language. Ed. by Paul Glasser. Trans. by Shlomo Noble. New Haven, CT: Yale University Press.

Weinreich, Uriel. 1968. Modern English-Yiddish Yiddish-English dictionary. New York: Schocken.

Weinreich, Uriel. 1981. College Yiddish: An introduction to the Yiddish language and to Jewish life and culture $\left(5^{\text {th }}\right.$ rev. edn.). New York: YIVO Institute for Jewish Research.

Weiß, Helmut. 2008. The possessor that appears twice: Variation, structure and function of possessive doubling in German. In Sjef Barbiers, Olaf Koeneman, Marika Lekakou \& Margreet van der Ham (eds.), Microvariation in syntactic doubling, 381401. Bingley: Emerald.

Weissberg, Josef. 1988. Jiddisch: Eine Einfübrung. Bern: Peter Lang.

Wexler, Paul. 1987. Explorations in Judeo-Slavic linguistics. Leiden: Brill.

Wolf, Meyer. 1969. The geography of Yiddish case and gender variation. In Marvin I. Herzog, Wita Ravid \& Uriel Weinreich (eds.), The Field of Yiddish: Studies in language, folklore and literature, vol. 3, 102-215. The Hague: Mouton.

Zesen, Philipp von. 1970. Sämtliche Werke, vol. 9: Deutscher Helicon (1641). Ed. by Ferdinand van Ingen. Rev. by Ulrich Maché. Berlin: De Gruyter.

Zifonun, Gisela. 2005. Der Dativ ist dem Genitiv sein Tod: Zur Analyse des adnominalen possessiven Dativs. In Franz Josef d'Avis (ed.), Deutsche Syntax: 
Theorie und Empirie. Symposium in Göteborg, 13.-15. Mai 2004, 25-51. Göteborg: Acta Universitatis Gothoburgensis.

Zwicky, Arnold. 1994. What is a clitic? In Joel A. Nevis, Brian D. Joseph, Dieter Wanner \& Arnold M. Zwicky (eds.), Clitics: A comprehensive bibliography, 1892-1991, xii-xx. Amsterdam \& Philadelphia, PA: John Benjamins.

Zwicky, Arnold \& Geoffrey K. Pullum 1983. Cliticization vs. inflection: English $n$ 't. Language 59.3, 502-513. 